\title{
Control Strategies to Reduce the Energy Consumption of Central Domestic Hot Water Systems
}

Jordan Dentz, Eric Ansanelli, Hugh Henderson, and Kapil Varshney Advanced Residential Integrated Energy Solutions 


\section{NOTICE}

This report was prepared as an account of work sponsored by an agency of the United States government. Neither the United States government nor any agency thereof, nor any of their employees, subcontractors, or affiliated partners makes any warranty, express or implied, or assumes any legal liability or responsibility for the accuracy, completeness, or usefulness of any information, apparatus, product, or process disclosed, or represents that its use would not infringe privately owned rights. Reference herein to any specific commercial product, process, or service by trade name, trademark, manufacturer, or otherwise does not necessarily constitute or imply its endorsement, recommendation, or favoring by the United States government or any agency thereof. The views and opinions of authors expressed herein do not necessarily state or reflect those of the United States government or any agency thereof.

Available electronically at SciTech Connect http:/www.osti.gov/scitech

Available for a processing fee to U.S. Department of Energy

and its contractors, in paper, from:

U.S. Department of Energy

Office of Scientific and Technical Information

P.O. Box 62

Oak Ridge, TN 37831-0062

OSTI http://www.osti.gov

Phone: 865.576.8401

Fax: 865.576.5728

Email: reports@osti.gov

Available for sale to the public, in paper, from:

U.S. Department of Commerce

National Technical Information Service

5301 Shawnee Road

Alexandria, VA 22312

NTIS http://www.ntis.gov

Phone: 800.553 .6847 or 703.605 .6000

Fax: 703.605.6900

Email: orders@ntis.gov 


\title{
Control Strategies to Reduce the Energy Consumption of Central Domestic Hot Water Systems
}

\author{
Prepared for: \\ The National Renewable Energy Laboratory \\ On behalf of the U.S. Department of Energy's Building America Program \\ Office of Energy Efficiency and Renewable Energy \\ 15013 Denver West Parkway \\ Golden, CO 80401 \\ NREL Contract No. DE-AC36-08GO28308 \\ Prepared by: \\ Jordan Dentz, Eric Ansanelli, Hugh Henderson, and Kapil Varshney \\ Advanced Residential Integrated Energy Solutions \\ The Levy Partnership, Inc. \\ 1776 Broadway, Suite 2205 \\ New York, NY 10019 \\ NREL Technical Monitor: Michael Gestwick \\ Prepared under Subcontract No. KNDJ-0-40347-05
}

June 2016 
The work presented in this report does not represent performance of any product relative to regulated minimum efficiency requirements.

The laboratory and/or field sites used for this work are not certified rating test facilities. The conditions and methods under which products were characterized for this work differ from standard rating conditions, as described.

Because the methods and conditions differ, the reported results are not comparable to rated product performance and should only be used to estimate performance under the measured conditions. 


\section{Contents}

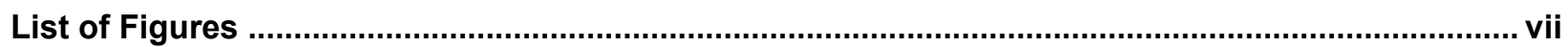

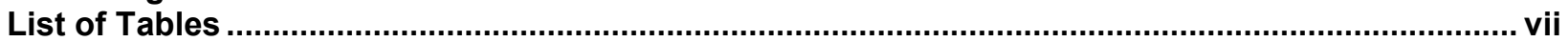

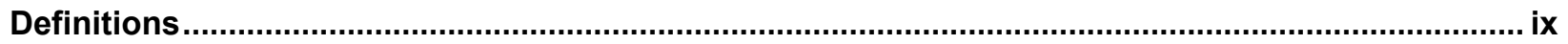

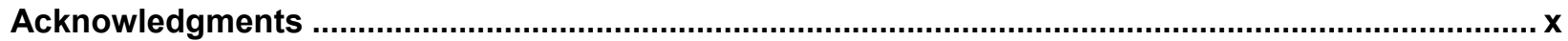

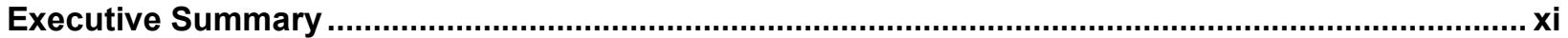

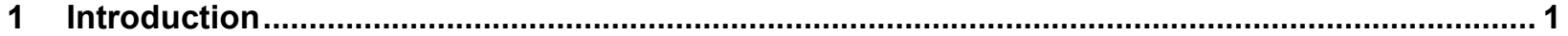

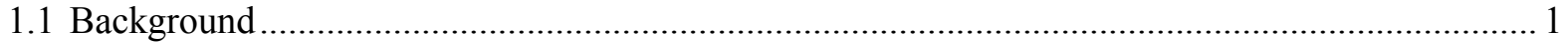

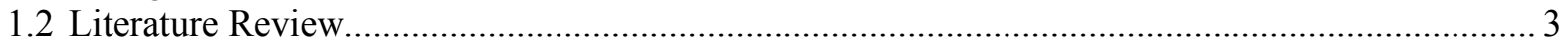

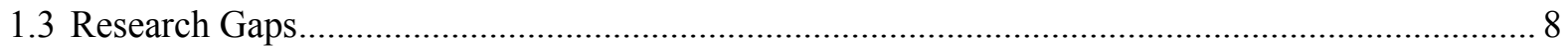

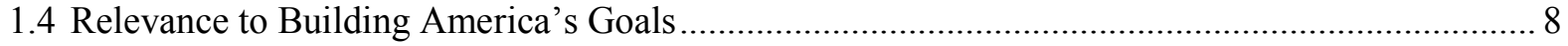

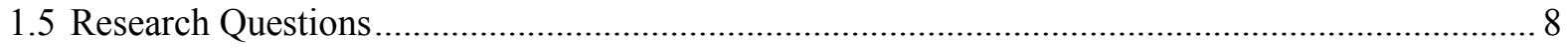

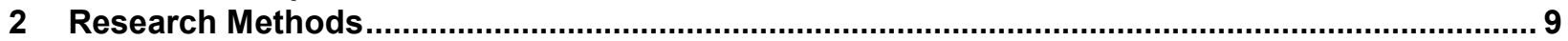

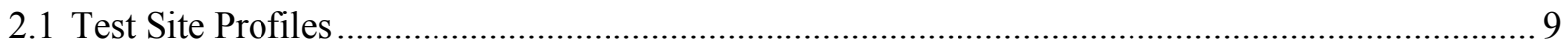

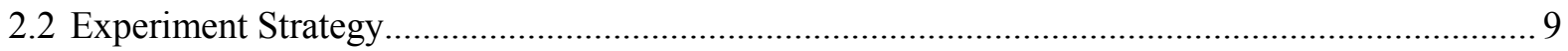

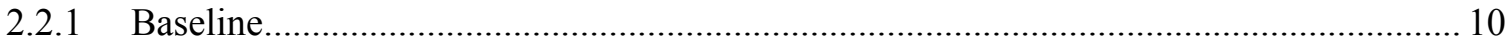

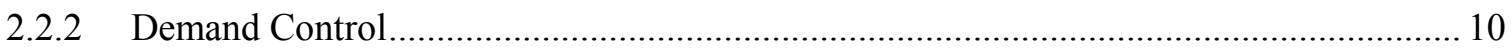

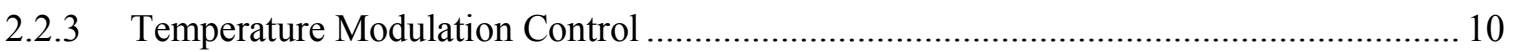

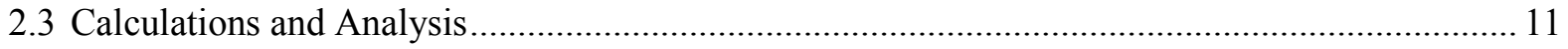

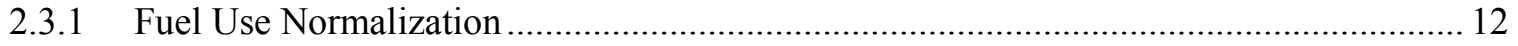

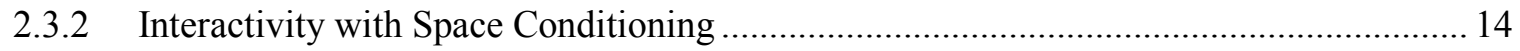

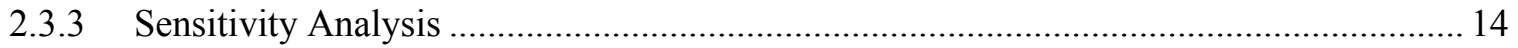

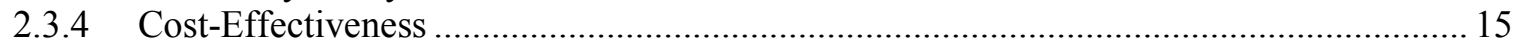

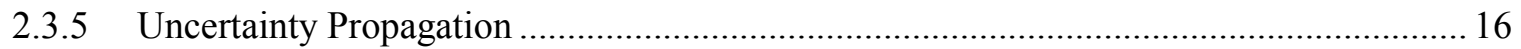

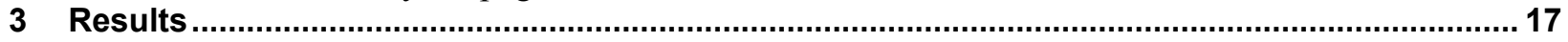

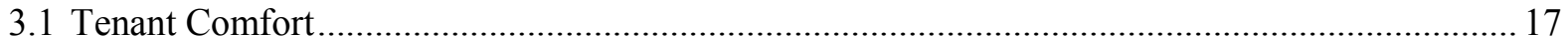

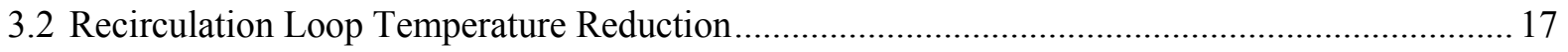

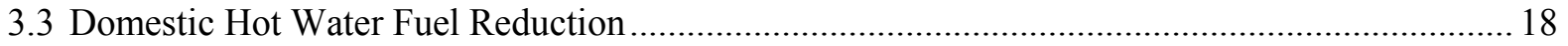

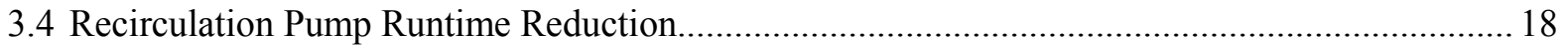

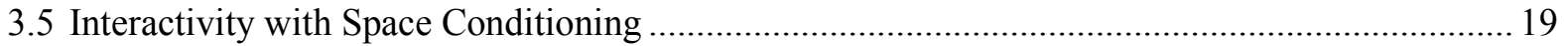

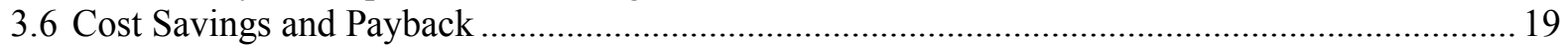

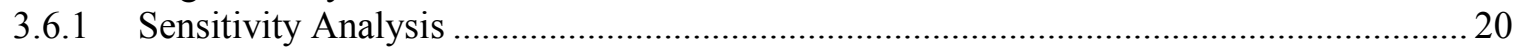

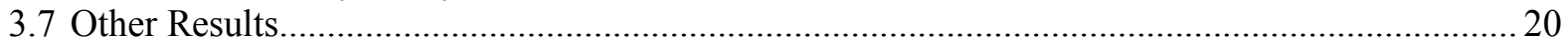

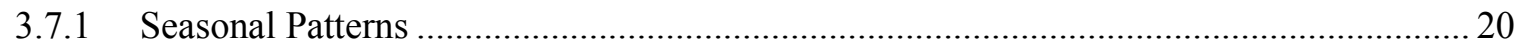

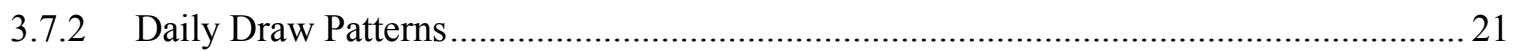

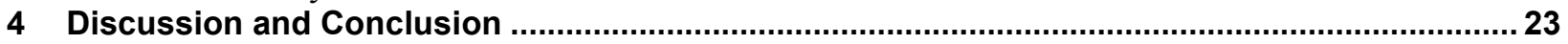

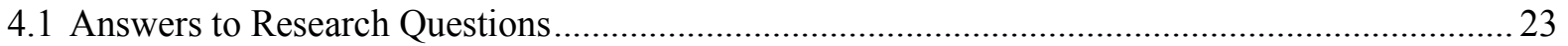

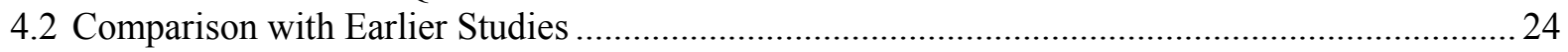

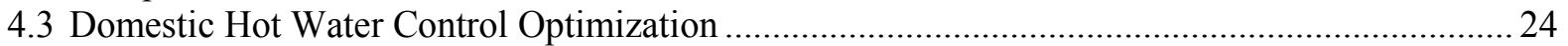

4.4 Importance of Commissioning Domestic Hot Water Systems ................................................... 24

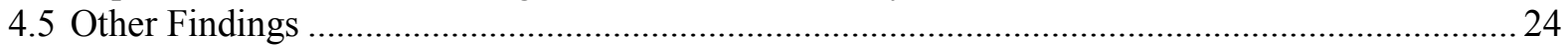

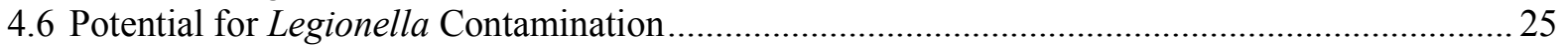

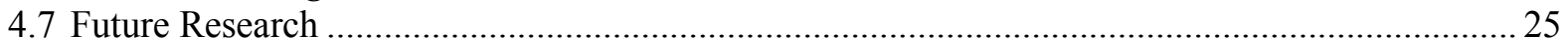

4.7.1 Modeling Space Conditioning Interactivity in Different Climates ................................. 25

4.7.2 Demand Recirculation Controls with Electronic and Mechanical Mixing Valves ........... 25

4.7.3 Effects of Demand Control on Tank Stratification and Associated Capacity and Safety

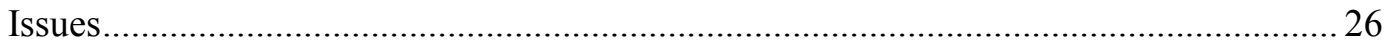

4.7.4 Effects of Crossover on Demand Recirculation Controls ..............................................26

Appendix A. Domestic Hot Water Energy Use Calculations ............................................................. 29 


\section{u.s. DEpartment of | Energy Efficiency \& \\ Renewable Energy}

Appendix B. Interactivity Calculation

38

Appendix C. Test Site Details

Appendix D. Common Domestic Hot Water Mixing Valves 


\section{List of Figures}

Figure 1. Residential Energy Consumption Survey end use for multifamily buildings...................... 1 Figure 2. Schematic of typical DHW recirculation loop in a multifamily building............................... 2 Figure 3. DHW demand recirculation control strategy flowchart (FMW = make-up water flow)....... 10

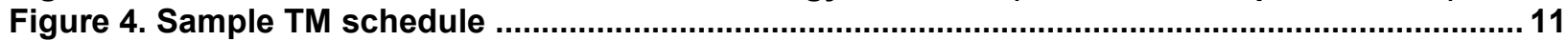

Figure 5. Sites $C$ and $D$ DHW system diagram and sensor locations .......................................... 12

Figure 6. Per-bedroom DHW consumption over monitoring period ................................................. 13

Figure 7. Street mains water temperatures over monitoring period ................................................. 14

Figure 8. Building B DHW supply temperature in temperature modulation mode over a 48-hour

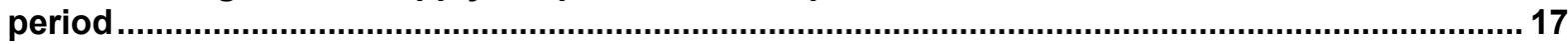

Figure 9. Seasonal variations in boiler runtime and make-up water temperature at building $B$....... 21

Figure 10. Collection of typical 24-hour DHW flow rates from test site A and B..............................222

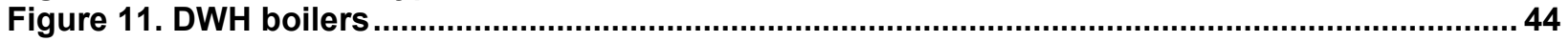

Figure 12. Current switch to monitor DHW boiler runtime (SB) ....................................................... 45

Figure 13. Current Switch to monitor runtime of the pump between the DHW boiler and the

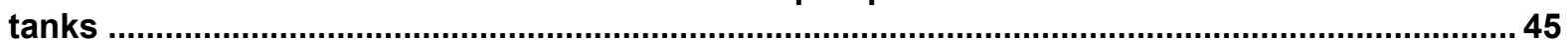

Figure 14. Supply water temperature (TS, left), recirculation loop temperature (TR, right)............. 45

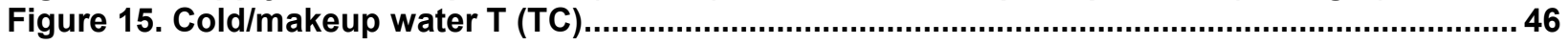

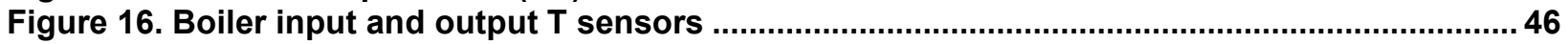

Figure 17. Flow sensor (left), and OPTO 22 data logger (right) ................................................. 46

Unless otherwise indicated, all figures were created by Advanced Research Integrated Energy Solutions.

\section{List of Tables}

Table 1. Energy Use Reductions and Costs Savings by Technique ............................................... xi

Table 2. Products Used with DHW Recirculation Systems.................................................................. 3

Table 3. Summary of Energy Savings by Control Techniques Compared to Continuous Pumping.. 7

Table 4. Test Site Profiles........................................................................................................... 9

Table 5. Space Conditioning Interactivity Modeling Assumptions................................................... 15

Table 6. DHW Average System Temperatures (Supply/Return) ….................................................. 17

Table 7. Annualized DHW Fuel Consumption and Reductions per Control Strategy ....................... 18

Table 8. Annualized Fuel Reduction Propagated Measurement Uncertainty ..................................... 18

Table 9. Recirculation Pump Savings with Demand Control........................................................... 19

Table 10. Calculated Annual Heating and Cooling Interaction for DHW Controls ............................ 19

Table 11. Annualized Total per-Bedroom DHW Costs and Savings with Space Conditioning

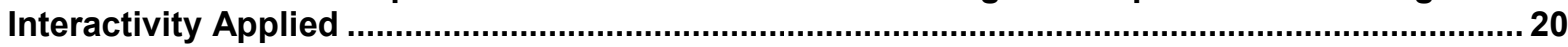

Table 12. Total Annual Baseline DHW Costs, Installed Control Costs, and Simple Payback per

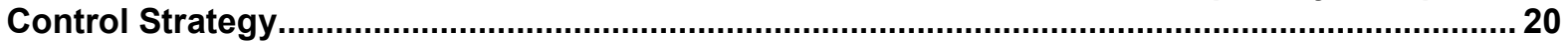

Table 13. Years Simple Payback Calculated for Sensitivity Analysis of Interactive Effects............. 20

Table 14. Building B Monitoring Period Profile Data ..................................................................... 31

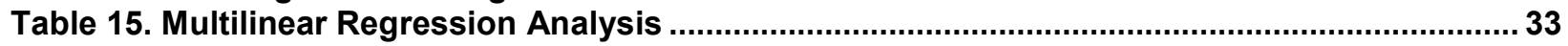

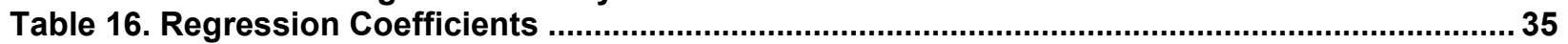

Table 17. Flow- and Temperature-Normalized Test Period Therms per Day ..................................... 35

Table 18. Flow- and Temperature-Normalized Fuel Reductions per Baseline Period ........................ 35

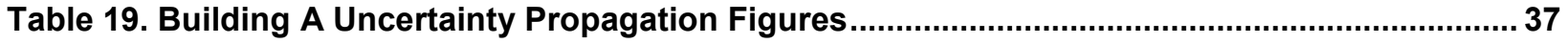

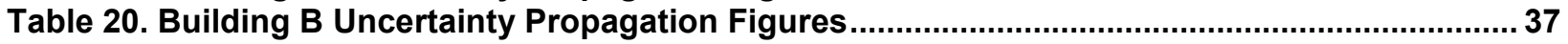

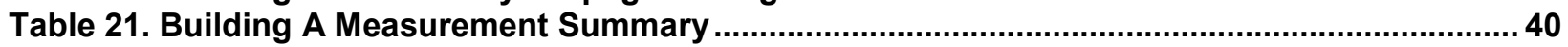

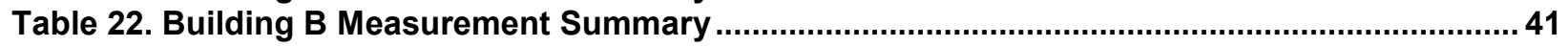

Table 23. Data Points Collected Continuously at Sites A and B ..................................................... 43

Table 24. One-Time Flow Measurements at Building A Using Ultrasonic Flow Meter.......................47 


\section{u.s. DEPARTMEnt of | Energy Efficiency \& \\ Renewable Energy}

Table 25. One-Time Flow Measurements at Building B Using Ultrasonic Flow Meter.

Table 26. DHW Tempering Valves ...

Unless otherwise indicated, all tables were created by Advanced Research Integrated Energy Solutions. 


\section{Definitions}

ACEEE

AFUE

DHW

GPD

HMG

SEER

TM
American Council for an Energy Efficient Economy

Annual Fuel Utilization Efficiency

Domestic Hot Water

Gallons per Day

Heschong Mahone Group

Seasonal Energy Efficiency Ratio

Temperature Modulation 


\section{Acknowledgments}

The authors would like to express their gratitude to the owners of the test site buildings; the Arker Companies represented by Allan Arker, Robert Gadero and Ilsoo Kim. Thanks also to Nathan Russel and Gregory Pedrick, who oversaw this work on behalf of the New York State Energy Research and Development Authority and Michael Gestwick of the National Renewable Energy Laboratory, who provided the same service on behalf of the U.S. Department of Energy's Building America Program. Finally, the authors acknowledge the invaluable technical support provided by Gabriel Ayala and Derek Zobrist of Enovative Group and Michael Keber of Tekmar Control Systems. 


\section{Executive Summary}

Domestic hot water (DHW) is the second-largest energy end use in U.S. buildings; it is exceeded only by space conditioning. Recirculation systems that consist of a pump and piping loops are commonly used in multifamily buildings to reduce wait time for hot water at faucets; however, constant pumping increases energy consumption by exposing supply and return line piping to continuous heat loss, even absent the demand for hot water. In this study, the U.S. Department of Energy's Building America research team Advanced Research Integrated Energy Solutions installed and tested two types of recirculation controls in a pair of buildings to evaluate their energy savings potential. Demand control, temperature modulation (TM) controls, and their simultaneous operation were compared to the baseline case of constant recirculation. Control and baseline modes were operated for 1 - to 3-week periods at a time and continuously rotated over a minimum of 8 months. To isolate the controls' effects on fuel use, daily average fuel consumption for each period was normalized against baseline fuel consumption for three parameters: makeup water temperature, supply temperature, and DHW volume.

Previous research that was conducted with distribution system controls (mainly in California) was used to select the two most promising control strategies for expanded research in New York. The interactive effects between DHW control fuel reductions and space conditioning (heating and cooling) were also estimated to make realistic predictions about the payback and financial viability of retrofitting DHW systems with these controls. Possible complications in the installation, commissioning, and operation of the controls were identified and solutions offered.

Table 1 shows the energy use reductions and cost savings in DHW fuel consumption.

Table 1. Energy Use Reductions and Costs Savings by Technique

\begin{tabular}{c|c|c|}
\hline Technique & $\begin{array}{c}\text { Annual Energy Savings } \\
(\mathbf{\%})\end{array}$ & $\begin{array}{c}\text { Annual Cost Savings } \\
(\mathbf{\%})\end{array}$ \\
\hline Demand Control & $7 \%$ & $8 \%$ \\
TM & $2 \%$ & $1 \%$ \\
\hline TM and Demand Control & $15 \%$ & $14 \%$ \\
\hline
\end{tabular}

The experiment results and discussion of installation and commissioning are targeted at researchers and engineering consultants. 


\section{Introduction}

In buildings with intermittent hot water use, recirculation loops can increase energy consumption by exposing the supply and return line piping to continuous heat loss, even when demand is low. For example, data collected from schools revealed that $90 \%$ of the system energy input was wasted because heat was lost from the distribution piping (Dinse and Henderson 2004). Similarly, distribution losses in multifamily buildings can account for $30 \%-50 \%$ of the energy input to the domestic hot water (DHW) system (Enovative Systems 2010b; Wendt et al. 2004). Research in California has shown that savings from controlling the DHW recirculation pump based on demand and modulating the supply temperature during off-peak hours can significantly reduce distribution losses and overall energy use. DHW system energy savings of $15 \%-25 \%$ are possible with these enhanced control strategies (Wendt et al. 2004). Field studies also have revealed that system configuration, return piping size, and pipe insulation levels also impact the system energy use and opportunities for reducing fuel consumption.

\subsection{Background}

In the United States, central DHW systems are commonly used in low- and high-rise multifamily buildings to provide DHW. Water heating is typically the second-largest energy end use in buildings; it is exceeded only by space conditioning (Sachs et al. 2011).

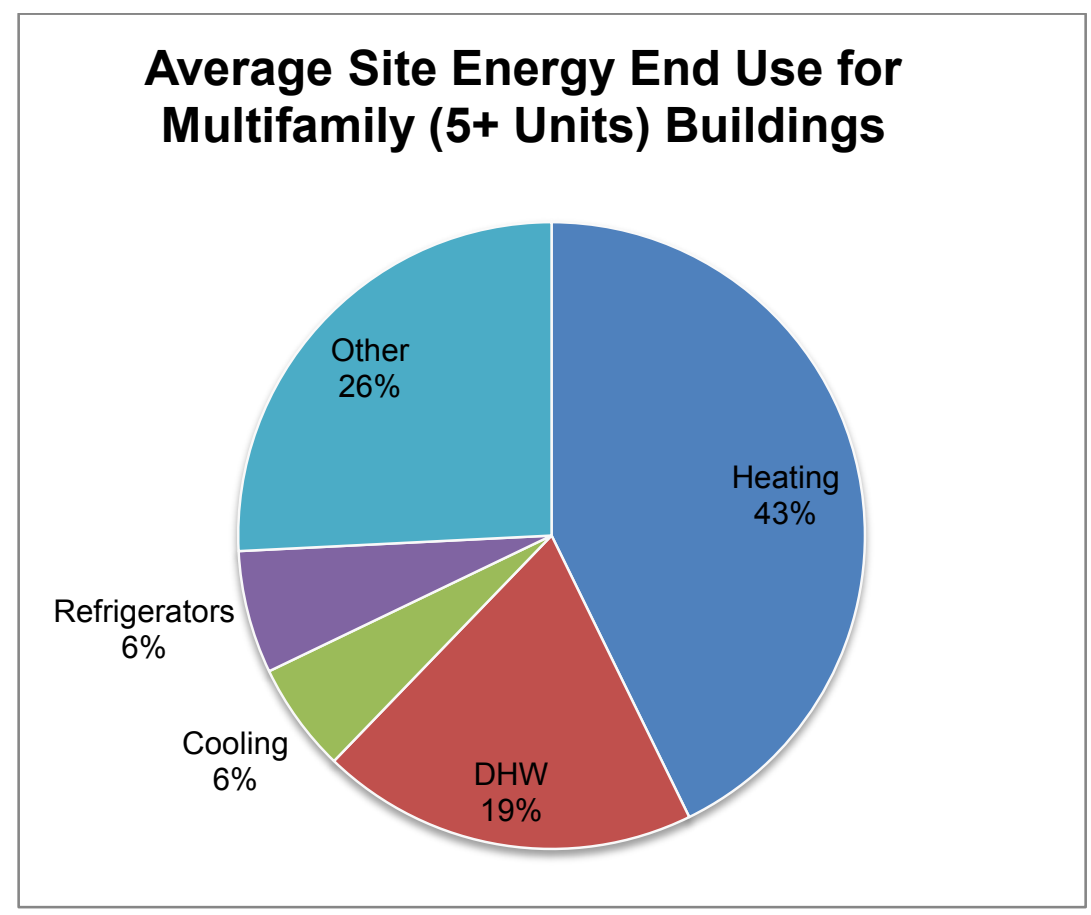

Figure 1. Residential Energy Consumption Survey end uses for multifamily buildings

Source: Energy Information Administration (2009)

DHW recirculation loops are more common in larger buildings because the hot water must be quickly provided to spaces that are far from the water heating plant. Most multifamily buildings with central DHW systems and more than 30-40 apartments generally have a recirculating system to enhance residents' comfort. The recirculation pump reduces wait time at the faucets by keeping the DHW piping loop hot as it gradually loses heat to the surrounding air. Without a 
recirculation pump, residents would have to run their faucets until the cooled, stagnant water is removed from the piping between the faucet and the DHW plant and would waste water in the process.

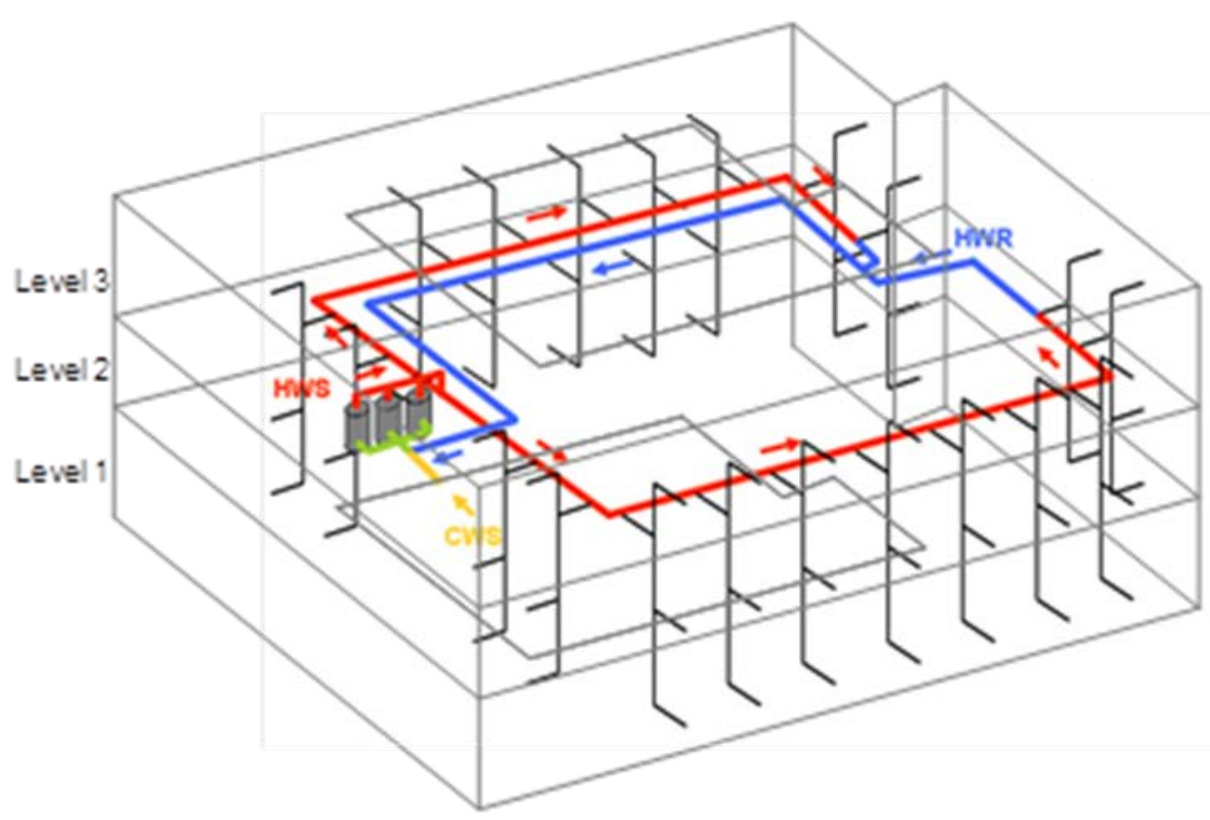

Figure 2. Schematic of typical DHW recirculation loop in a multifamily building

Source: Heschong Mahone Group, used with permission

In many multifamily buildings, these systems are uncontrolled and recirculation pumps run continuously. However, several DHW control strategies have been developed in an attempt to save energy. The five most commonly employed DHW control strategies are:

- Temperature control. An aquastat control is used to switch the recirculating pump on and off to maintain a target temperature in the loop.

- Timer control. A timer is used to turn the recirculating pump on during peak usage times and off overnight.

- Timer control in conjunction with temperature control.

- Temperature modulation (TM) control. The control system lowers the DHW set point temperature when hot water demand is expected to be low.

- Demand control. The recirculation pump is controlled based on demand (flow) and return water temperature.

Table 2 provides a list of DHW control manufacturers and products. Timer, temperature, and timer with temperature controls cost \$25-\$200; demand and TM controls cost \$750-\$2,000 (Lutz 2008). Timer and temperature controls are the most commonly used of these systems; however, they are less effective than demand and TM controls. A key limitation of timer controls is that if users demand hot water when the pump is off, they may waste water as they wait for the temperature to increase. Temperature control is limited because it reduces pump electricity use only and keeps the recirculation piping hot even absent demand; therefore, temperature control 
does not reduce DHW fuel use. An exception would be if the aquastat is set to maintain a recirculation temperature that is lower than the supply temperature.

Table 2. Products Used with DHW Recirculation Systems in Residential and Commercial Buildings

\begin{tabular}{|c|c|c|c|c|}
\hline Manufacturer & Model & $\begin{array}{l}\text { Control } \\
\text { Type }\end{array}$ & $\begin{array}{l}\text { Equipment } \\
\text { Cost }\end{array}$ & Notes \\
\hline Grundfos & UP 23-96 & $\begin{array}{l}\text { None- } \\
\text { continuous }\end{array}$ & $\$ 200$ & $\begin{array}{c}\text { Pump power: } 1 / 12 \mathrm{HP} \\
\text { Standard pump that } \\
\text { continuously recirculates the } \\
\text { DHW loop }\end{array}$ \\
\hline Bell \& Gossett & AQS-3/4 & Thermostatic & $\$ 40$ & $\begin{array}{l}\text { Aquastat control that switches } \\
\text { recirculating pump on and off }\end{array}$ \\
\hline Honeywell & L6006C1018 & Thermostatic & $\$ 120$ & $\begin{array}{l}\text { Aquastat control that switches } \\
\text { recirculating pump on and off }\end{array}$ \\
\hline Danfoss & $\begin{array}{l}\text { CCR2 } \\
\text { Module }\end{array}$ & $\begin{array}{l}\text { Timer and } \\
\text { thermostatic }\end{array}$ & - & $\begin{array}{l}\text { Time clock and aquastat that } \\
\text { control recirculation pump }\end{array}$ \\
\hline Aerco & E8 Controller & $\mathrm{TM}$ & - & $\begin{array}{c}\text { Water heater temperature set } \\
\text { point controlled to vary } \\
\text { depending on DHW load }\end{array}$ \\
\hline Enovative & DCP-9913 & Demand & $\$ 1,100$ & $\begin{array}{c}\text { Flow and temperature control } \\
\text { of recirculation pump }\end{array}$ \\
\hline $\begin{array}{c}\text { Advanced } \\
\text { Conservation } \\
\text { Technology, } \\
\text { Inc. }\end{array}$ & STS series & Demand & $\begin{array}{l}\$ 399-\$ 893 \\
+\$ 55-\$ 198 \\
\text { for wireless }\end{array}$ & $\begin{array}{c}\text { Flow and temperature control } \\
\text { of recirculation pump for } \\
\text { single-family homes }\end{array}$ \\
\hline
\end{tabular}

\subsection{Literature Review}

The literature review revealed examples of measured typical DHW system component efficiencies, savings for the same controls that were tested in this study, and DHW controls that are improperly commissioned.

A meta-analysis of DHW research performed by the American Council for an Energy Efficient Economy (ACEEE) showed that typical uncontrolled multifamily residential and commercial DHW systems range in efficiency from $23 \%$ to $49 \%$; that is, only $25 \%-50 \%$ of the energy put into heating the water reaches the tap (Sachs et al. 2011). Coincidentally, distribution losses in multifamily DHW systems are roughly comparable to those in single-family housing with conventional trunk-and-branch systems, according to this report. One referenced study achieved DHW fuel savings of $15 \%$ for demand control, $9 \%$ for a simple pump timer, and $10 \%$ for thermostat pump control; however, the results from a utility-scale retrofit program were only a 
fraction of forecast savings (Enovative Systems 2011a). Researchers posited that this might have been due to design and installation errors such as missing insulation and water leaks; each of the 139 buildings in the program had at least one such fault.

Lutz (2008) conducted research to improve the efficiency of water heaters and hot water distribution systems in multifamily residential buildings in California. The three multifamily buildings studied had failed or overridden time clocks, failed recirculation pumps, and a wide variety of supply and return temperatures (including excessively high temperatures that wasted energy and could cause scalding). The results revealed that a great deal of energy may be wasted in multifamily buildings throughout California because of failed DHW system components and incorrect system set points. The authors suggested that these problems could be remedied by initial commissioning, retrocommissioning, or continuous automatic monitoring with fault reporting and diagnosis.

Enovative, a vendor of DHW controls, conducted a study at 35 multifamily residential and commercial buildings, mainly in California (Zobrist 2010). The residential buildings ranged in size from 20 to 189 units with an average of 44 . The vendor installed dedicated gas meters to isolate central water heater and boiler use and installed data loggers to track recirculation pump electricity consumption. Continuous recirculation and demand control were alternated weekly over a 2-month period. The results estimated average natural gas savings per site to be approximately 1,526 therms/year (35 therms/unit) and estimated electricity savings to be 1,236 $\mathrm{kWh} /$ year $(28 \mathrm{kWh} / \mathrm{unit}$, based on a demand pump run time of about 1.8 hours/day).

The Heschong Mahone Group, Inc. (HMG 2010) conducted field monitoring of DHW systems in more than 30 multifamily buildings in California and assessed the energy-saving potential of three control strategies. The researchers estimated energy loss for the different system components as a percentage of total consumption during continuous recirculation: $45 \%$ at the water heater, $5 \%-30 \%$ from the distribution loop, and $2 \%$ from the branches. Researchers noted that pipe insulation can keep the recirculation loop warm for as long as 1 hour, and pumps can be shut off periodically during peak use. The report made several recommendations:

- An ideal control strategy would be to turn on the recirculation pump periodically and modulate the water heater temperature during off-peak periods.

- Proper system sizing is the best way to reduce standby and short-cycling losses because water heater efficiency is the most important component to overall system efficiency.

- Running the recirculating loop through the middle of the building can minimize pipe length and improve system efficiency.

Sempra Energy (2010) compared demand recirculation pump controls to continuous recirculation to determine if fuel or water savings could be realized without affecting occupant comfort. Testing was performed in a single commercial building with 12 tenant spaces in California. Results showed that the DHW system that was equipped with a demand-controlled pump consumed about $12 \%$ less natural gas.

HMG surveyed more than 50 multifamily residential and commercial buildings and monitored DHW systems in 32 buildings of various sizes, DHW system designs, recirculation loop configurations, and occupancy types throughout California (California Utilities Statewide Codes 
and Standards Team 2011). Researchers found that, on average, only $35 \%$ of the energy input in central DHW systems was reaching the end user; 33\% was lost in the recirculation loop, $1 \%$ in the branch pipes, and about $31 \%$ at the water heater. The performance of three recirculation loop control technologies was investigated: timer control, TM, and demand control. In addition to highlighting control savings potential, the report emphasized the importance of distribution system layout (location, pipe diameter, and insulation) to system performance. Based on interviews with manufacturers, the report estimated that demand control equipment costs about $\$ 1,000$ for each recirculation loop system, installation cost is about $\$ 200$, and the equipment useful lifetime is about 15 years.

The Benningfield Group (2009) conducted a study of DHW controls at 35 multifamily residential buildings in California. The researchers found a wide variance in savings across individual installations. The larger the storage tank, the greater the savings. The explanation posited was that with continuous recirculation pumping, cold water is constantly mixed with hot water in storage and thus requires more frequent boiler firing. When the pump operation changes from continuous to demand controlled, hot water stratifies during periods of low demand and effectively reduces the volume of adequately heated DHW stored in the tank. As the tank size increases, the stratum of hot water available at the top of the tank also increases, which allows the boiler to run less frequently. With a small tank, the boiler will likely need to fire every time a resident calls for hot water. The results show that average natural gas savings per apartment attributable to DHW controls were 34.7 therms/year and average electricity savings were 30.1 $\mathrm{kWh} /$ year.

Testing performed by Enovative in two multifamily residential buildings in California with 20 and 70 units, respectively, showed that after replacing the older pumps with demand recirculating controls, average annual gas savings were $16 \%$ or 745 therms $(\$ 745)$, and electricity use was reduced by more than $98 \%$ or $1,756 \mathrm{kWh}(\$ 210)$. Total average annual savings were $\$ 32$ per apartment (Enovative Systems 2010b).

In a project funded by the New York State Energy Research and Development Authority, three control strategies were implemented in six multifamily residential buildings (Goldner 1999). These control strategies were:

- Shut down overnight.

- Shut down during peak morning and evening hours.

- Cycle by return line aquastat set to $110^{\circ} \mathrm{F}$.

Savings were $6 \%, 6 \%$, and $11 \%$, respectively, compared with continuous recirculation. A major factor in DHW consumption was the number of persons living in the building. Vacancy figures were used to eliminate DHW consumption variances that were caused by differing occupancy levels and to adjust DHW consumption per occupied apartment. Adjustments were also made to account for occupant behavior that resulted from the variable inlet water temperatures during each period. The amount of DHW being recirculated under the non-baseline scenarios was greatly reduced, which was the major contributor toward energy savings under the other strategies. Typically a moderate reduction was observed in recirculated water from continuous operation compared to the other three strategies. Switching from continuous operation to return line aquastat control reduced the amount of water recirculated annually by an average of $74 \%$. 
The reduction in DHW temperature under all the control strategies also contributed to the energy savings, because the systems were not circulating higher temperature DHW around the buildings as often.

HMG (2006) conducted research on DHW systems in two multifamily residential buildings in California. The company implemented several control systems and showed that controls on hot water recirculation systems in multifamily buildings reduce gas consumption by either reducing the temperature of the hot water being circulated (when the hottest water is not needed) or by turning off the recirculation pump when it is not needed. The degree to which controls save energy varies by the number of end users on the hot water circulation system, configuration of water heating and storage devices, type of control, and other factors. HMG also showed that demand controls can save 0.5-9.2 MBtu/unit/year and the temperature modulating controls can save 0-7.3 MBtu/unit/year. Projected energy savings are summarized in Table 3.

Several other case studies about DHW system controls in commercial and multifamily residential buildings (Benningfield Group 2008; Enovative Systems 2008, 2009, 2010a,b, 2011a) have also shown that recirculation pump time can be reduced compared to uncontrolled DHW systems if a demand-type control system is implemented.

The most common control types installed on the recirculation loops of DHW distribution systems (based on the literature review) are timers, temperature controls, and timer-temperature combination controls. Demand controls and TM controls are not commonly installed; however, the literature shows that these strategies are the most effective energy savers. A forthcoming New York State Energy Research and Development Authority study that was undertaken in conjunction with the present research determined the monetary savings incurred by retrofitting demand controls, TM controls, and demand combined with TM controls in midrise and high-rise multifamily buildings, both in New York (Levy Partnership, forthcoming). The calculated savings (Table 3) factored the measured reductions in boiler runtime and the assumed interactive effects of DHW control implementation with space-conditioning demands, mirroring the approach taken in this study. 
Table 3. Summary of Energy Savings by Control Techniques Compared to Continuous Pumping

\begin{tabular}{|c|c|c|c|c|}
\hline Report & Location & Building Characteristics & Control Type & $\begin{array}{l}\text { Annual Savings versus } \\
\text { Continuous Recirculation }\end{array}$ \\
\hline Benningfield Group (2009) & California & 35 sites, 1,540 units & Demand & 35 therms/unit \\
\hline Enovative (2008) & Los Angeles, CA & 5 stories, 50 units & Demand & $30 \%$ gas \\
\hline Enovative (2009) & Los Angeles, CA & 5 stories, 189 units & Demand & $12 \%$ gas \\
\hline Enovative (2010a) & Escondido, CA & 2 stories, 8 units & Demand & 18\% DHW electricity \\
\hline Enovative (2010b) & Irvine, CA & 3 stories, 21 units & Demand & $16 \%$ gas \\
\hline Enovative (2011a) & Malibu, CA & 30 units & Demand & $15 \%$ gas \\
\hline \multirow{3}{*}{ Goldner (1999) } & \multirow{3}{*}{ New York, NY } & \multirow{3}{*}{6 sites, 5-6 stories, $25-103$ units } & Timer (nighttime off) & $6 \%$ \\
\hline & & & Timer (peak hours off) & $6 \%$ \\
\hline & & & Return temperature & $11 \%$ \\
\hline \multirow{6}{*}{ HMG (2008) } & \multirow{3}{*}{ Saint Helena, CA } & \multirow{3}{*}{2 stories, 8 units } & Demand & $44 \%$ \\
\hline & & & $\mathrm{TM}$ & $35 \%$ \\
\hline & & & Timer (late evening off) & $1 \%$ \\
\hline & \multirow{3}{*}{ Oakland, CA } & \multirow{3}{*}{3 stories, 121 units } & Demand & $5 \%$ \\
\hline & & & Return temperature & $-5 \%$ \\
\hline & & & Timer (late evening off) & $-1 \%$ \\
\hline \multirow{6}{*}{$\begin{array}{c}\text { Levy Partnership } \\
\text { (forthcoming; includes } \\
\text { estimated space- } \\
\text { conditioning interactivity) }\end{array}$} & \multirow{6}{*}{ New York, NY } & \multirow{3}{*}{7 stories, 54 units } & Demand & $11 \%$ \\
\hline & & & TM & $1 \%$ \\
\hline & & & Demand and TM & $13 \%$ \\
\hline & & \multirow{3}{*}{15 stories, 122 units } & Demand & $8 \%$ \\
\hline & & & $\mathrm{TM}$ & $6 \%$ \\
\hline & & & Demand $+\mathrm{TM}$ & $10 \%$ \\
\hline
\end{tabular}




\subsection{Research Gaps}

As noted in Table 3, all but one of the aforementioned studies about DHW controls was performed in California, where a mild climate prevails. Only one study has been conducted in the colder Northeast where the outdoor temperature can drop to as low as $-25^{\circ} \mathrm{F}$. Outdoor air temperature can have a significant impact on cold water makeup temperature and DHW use. Because of behavioral effects, DHW use tends to be higher in colder weather than in warmer weather. Furthermore, the interactive effects between the DHW system and the building heating and cooling system were not considered in these previous studies.

\subsection{Relevance to Building America's Goals}

This project addresses the following Building America Implementation Standing Technical Committee milestone:

Develop and demonstrate multifamily recirculation control strategies that reduce average recirculation losses by $15 \%$ compared to continuously operating recirculation systems (NREL 2012).

\subsection{Research Questions}

This research addressed the following questions:

- How do DHW control strategies compare to the baseline case and to each other in terms of energy savings in the Northeast?

- How do interactive effects between DHW energy savings and the heating/cooling loads affect the cost-effectiveness of DHW control retrofits?

- What is the cost-effectiveness of DHW control system retrofits in typical low-rise multifamily buildings? 


\section{Research Methods}

\subsection{Test Site Profiles}

Table 4 summarizes some of the relevant characteristics of both study sites. The two properties were three-story sister buildings in Brooklyn, New York. Their mechanical systems and architecture were the same; their footprints and total number of units varied slightly. Data were collected across all four seasons for each property. Demand control, TM control, and the combination of both were tested at building B; only demand controls were tested at building A.

Table 4. Test Site Profiles

\begin{tabular}{|c|c|c|}
\hline Site & Building A & Building B \\
\hline Location & East New York, Brooklyn & East New York, Brooklyn \\
\hline Collection Period & August 2013-April 2014 & August 2013-March 2014 \\
\hline Control Methods Tested & Demand and continuous & $\begin{array}{c}\text { Demand; TM; demand and } \\
\text { TM; continuous }\end{array}$ \\
\hline DHW System & $\begin{array}{l}\text { Dedicated boiler and } \\
\text { storage tank }\end{array}$ & $\begin{array}{l}\text { Dedicated boiler and storage } \\
\text { tank }\end{array}$ \\
\hline Number of Floors & 3 & 3 \\
\hline Number of Units & 54 & 48 \\
\hline Number of Bedrooms & 81 & 72 \\
\hline Average Supply Temperature & $159^{\circ} \mathrm{F}$ & $131^{\circ} \mathrm{F}$ \\
\hline Average DHW GPD/Bedroom & 38 & 41 \\
\hline Measured DHW Boiler Efficiency & $83 \%$ & $85 \%$ \\
\hline
\end{tabular}

The existing DHW controls malfunctioned and could not be repaired during the monitoring period, so the average supply temperatures at building A were higher than desired. Measured steady-state DHW boiler efficiencies were $83 \%-85 \%$. Each building was equipped with window or through-wall air conditioners. The DHW pipes were insulated with $1 / 2$-in. fiberglass.

\subsection{Experiment Strategy}

Demand control systems were installed at both multifamily test sites (referred to as Building A and Building B), and a TM system was installed at one of the sites to evaluate the impacts of DHW control strategies. Each control strategy was compared with the baseline (continuous circulation, constant temperature) case.

At Building A, each mode operated for 1-3 weeks before changing to the next mode. This was repeated for 8 months while the sensor data were logged. This approach enabled the team to develop a comprehensive set of data for all the test strategies through all four seasons. At Building B, the control installation timeline did not allow for TM controls to be tested across all seasons; thus, it required the analysis approach described in Section 2.3. Building superintendents were interviewed and tenants were given surveys to determine whether resident satisfaction continued to be met while the controls were in operation.

The control modes are described in Sections 2.1.1 through Section 2.2.3. 


\subsubsection{Baseline}

The recirculating pump runs continuously and the DHW supply water set point remains constant. If the building is equipped with hot water storage tanks, as is the case in the two test buildings, the supply temperature is controlled by a storage tank sensor that periodically calls for heat from the boiler. If the building does not have storage tanks, hot water $\left(160^{\circ} \mathrm{F}\right.$ or higher $)$ from a dedicated DHW boiler or from a heat-exchange coil in the space heating boiler is mixed with cold water by a mixing valve to achieve the desired supply temperature. Continuously recirculating, constant supply temperature DHW is the mode of operation most commonly encountered in multifamily buildings and serves as the baseline for comparison with the control strategies.

\subsubsection{Demand Control}

Demand control uses the following equipment:

- A flow sensor installed on the makeup water pipe

- A temperature sensor installed on the recirculating line return pipe

- A programmable switch that turns the recirculating pump on and off.

With demand controls installed and operating, the recirculation pump runs only if a resident calls for hot water (i.e., if the makeup flow sensor is triggered) and the temperature of the recirculation water has fallen below a set point temperature of $100^{\circ} \mathrm{F}$. If the pump has been idle for more than 5 hours, the controller activates it until the temperature of the return water exceeds $110^{\circ} \mathrm{F}$ (set point plus $10^{\circ} \mathrm{F}$ differential). The $100^{\circ} \mathrm{F}$ set point is adjustable. Figure 3 shows a flow chart of this control strategy.

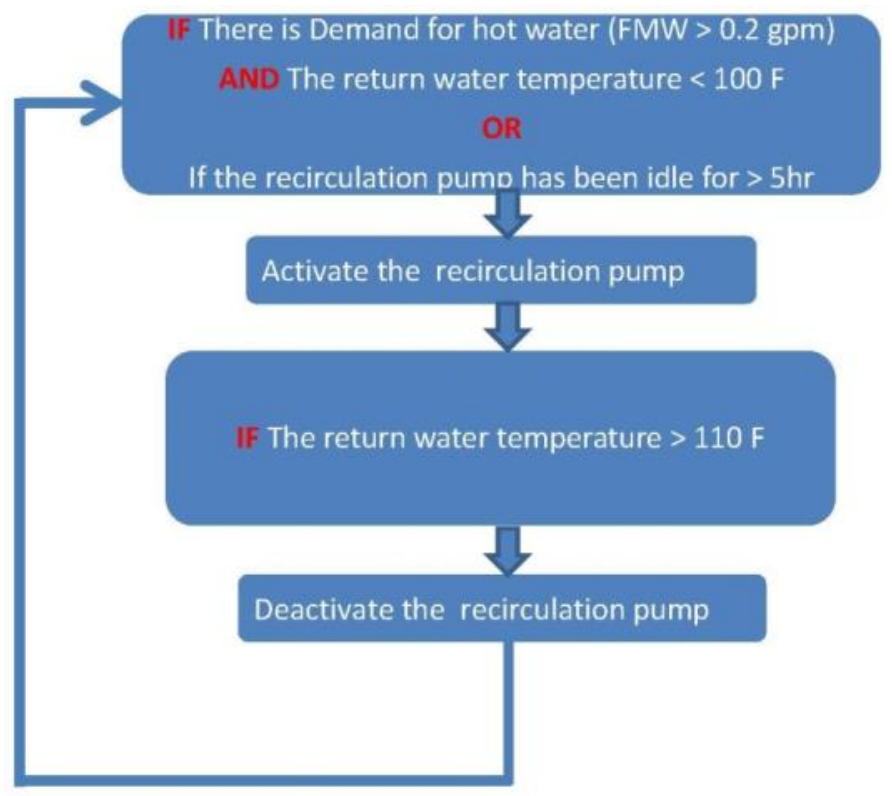

Figure 3. DHW demand recirculation control strategy flowchart (FMW = makeup water flow)

\subsubsection{Temperature Modulation Control}

In this case, the recirculation pump runs continuously while the supply water temperature is varied hourly according to the expected demand. The TM control is programmed to lower supply 
temperature at night (when demand is expected to be minimal) and to raise the supply temperature during the mornings and early evenings, which are peak times. Supply temperature is also lowered during the midday hours when demand is thought to be moderate (Figure 4). This strategy lowers the average DHW temperature within the distribution piping and still allows the occupants to obtain their desired hot water temperature at all times by mixing more or less cold water in at the tap. The possibility of decreasing the average modulating temperature further than that used in this study is discussed in Section 4.

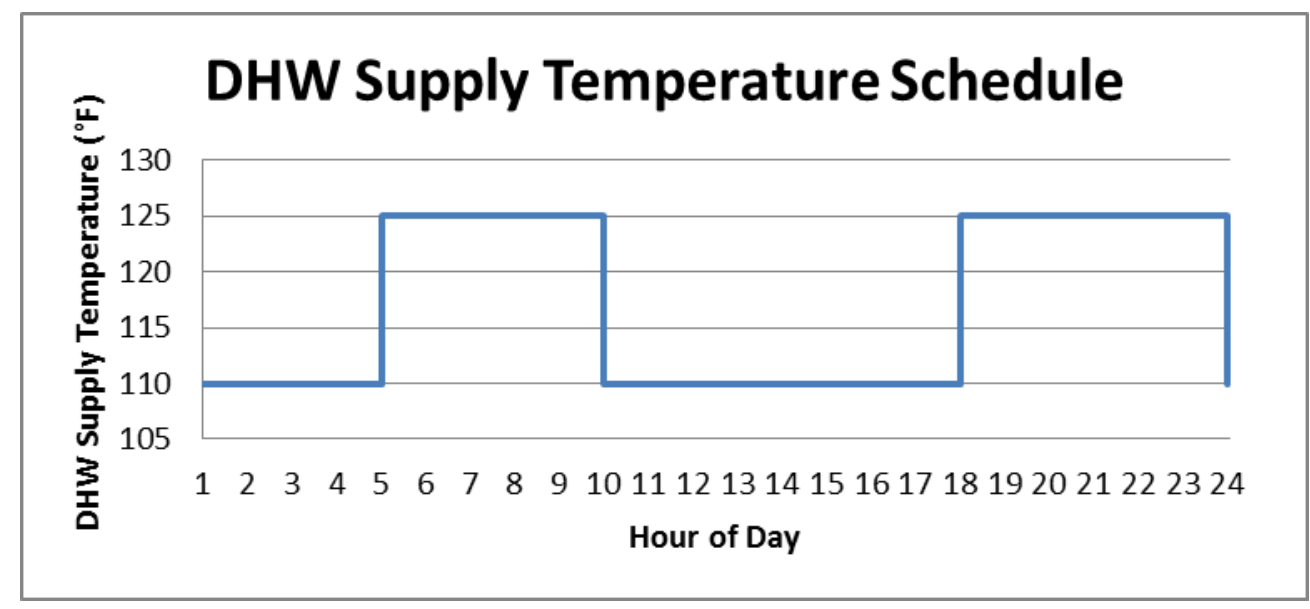

Figure 4. Sample TM schedule

The equipment that was used to implement the TM control strategy at Building B included an aftermarket boiler controller that could be programmed with two temperature set points and four schedule periods per day.

\subsection{Calculations and Analysis}

During the monitoring period for each building, various data points were collected continuously, including DHW supply and return temperature, makeup water temperature, boiler and pump runtime, and makeup water flow (volumetric DHW consumption). Figure 5 shows the sensor placement for each building; complete lists of monitoring locations and equipment are included in Appendix C. Total DHW energy use was calculated for each period in the alternating cycle of control modes using the formulae in Appendix A. Daily average fuel consumption for each test period was normalized against and compared with the nearest control period for Building A; an alternative method was used for Building B, as described in Section 3. A weighted annual average of the DHW fuel and recirculation pump electricity reductions for each strategy employed at each test site was compared with the average baseline consumption, then calculated and presented. 


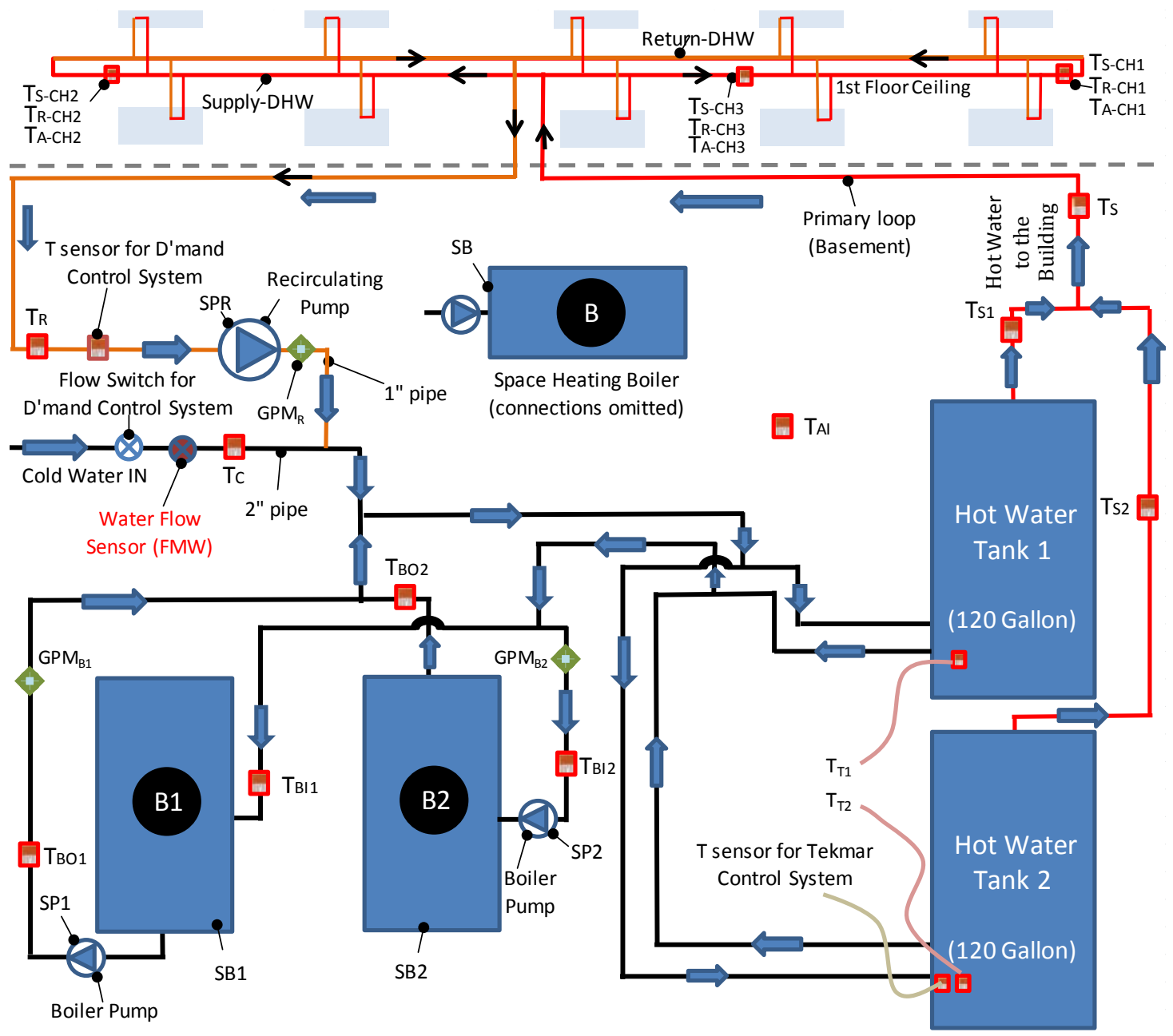

Figure 5. Sites A and B DHW system diagram and sensor locations

\subsubsection{Fuel Use Normalization}

The total DHW energy use for each test period was normalized against the nearest baseline period with respect to three parameters:

- Gallons of DHW consumed

- Incoming cold water temperature

- DHW supply temperature.

Normalizing the fuel use per period in this manner was done in an attempt to minimize the influence of seasonal factors in fuel use and to enable a more direct comparison between the baseline DHW fuel consumption and the performance of the controls in the test cases. The fuel normalization calculations for building A are given in expanded form in Appendix A. At site B, because the strategies of TM and demand control combined with TM were tested back-to-back in the wintertime only, and without alternating periods of baseline operation, multilinear regression was used to normalize test period energy use and compare it to the baseline periods; this method is also detailed in Appendix A. 
Seasonal trends in resident behavior and changes in occupancy may cause the total volume of DHW consumption to vary. Figure 6 shows the average daily consumption in gallons per bedroom (a proxy for number of occupants) over the data collection period for both test sites. The graph shows that winter per-capita DHW consumption was higher than summer at both buildings. Lower per-bedroom consumption at Building A may be caused by the elevated average supply temperature at that site.

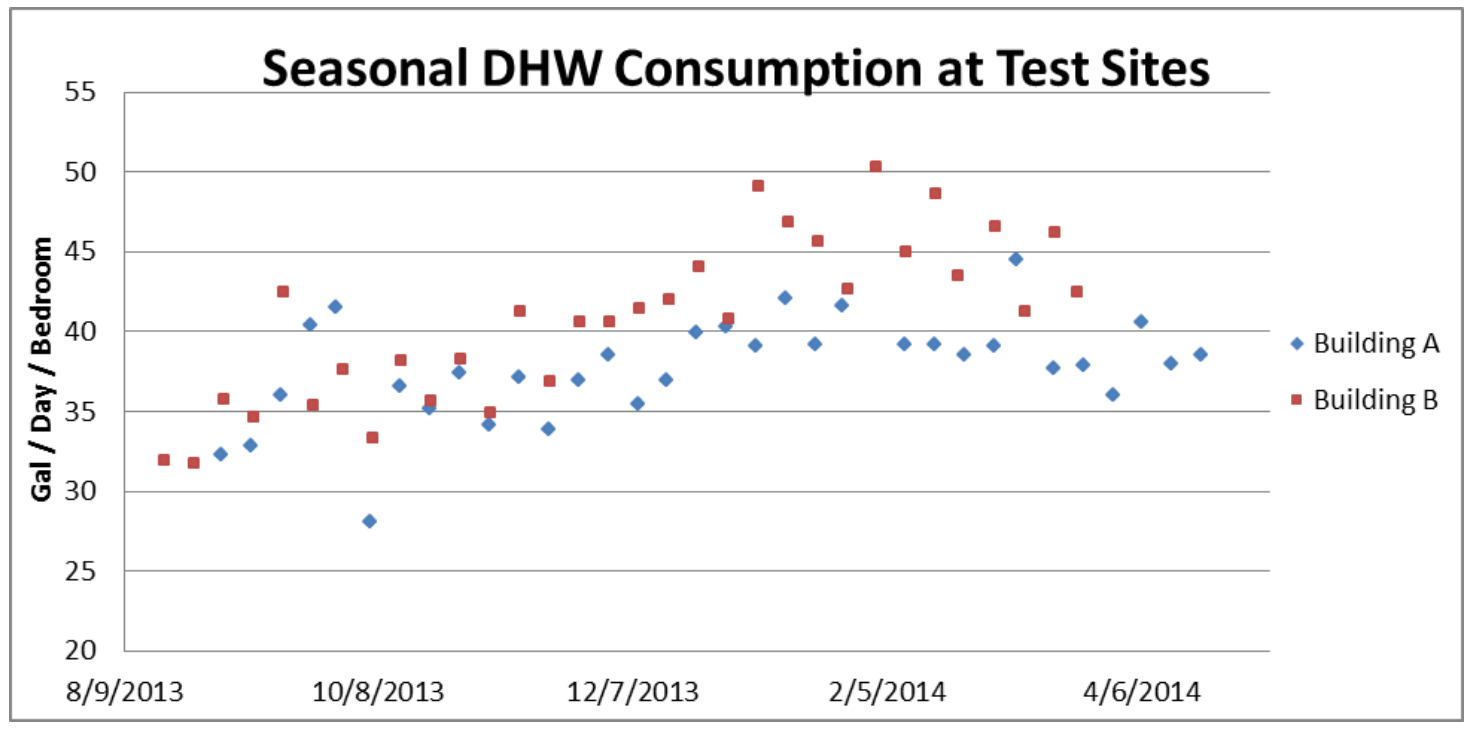

Figure 6. Per-bedroom DHW consumption over the monitoring period

Figure 7 shows that the temperature of makeup water varied by more than $30^{\circ} \mathrm{F}$ at the test buildings and required much more heat to be added during winter months when the makeup water temperature was lowest to heat the DHW to the desired supply temperature.

Normalizing with respect to the difference between the makeup water temperature and the supply temperature was necessary because both points shifted throughout the monitoring period at both buildings: makeup temperature because of seasonal variation, and average supply temperature both by design (in TM mode) and by circumstance because of inconsistent boiler and system behavior. However, because TM mode is partly responsible for the increased volumetric DHW consumption within the same periods, the resulting "delta $\mathrm{T}$ " normalization factor that increased calculated energy use for periods of TM mode was offset by the "daily DHW volume" normalization factor. Thus, seasonal and other confounding factors in the final energy consumption were accounted for as well as something very close to the true energy savings from the TM control regime. This method is definitely not perfect, but the authors found no better way to account for real-word variations in temperature and flow. 


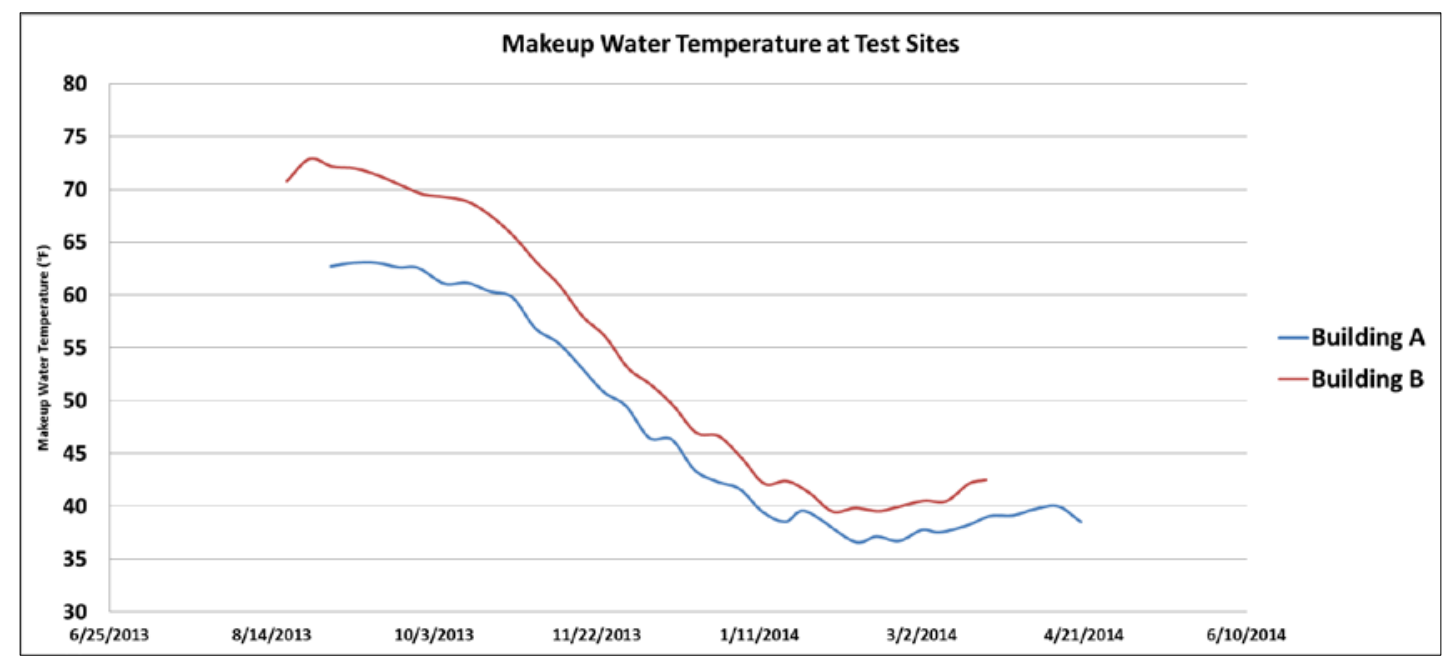

Figure 7. Street mains water temperatures over the monitoring period

\subsubsection{Interactivity with Space Conditioning}

DHW controls increase system efficiency via two mechanisms: the reduction of pump electricity use and the reduction of heat loss from the loop of recirculation pipe into the surrounding space (e.g., pipe chases and basement hallways). The latter can increase building demand for space heating and reduce the demand for cooling. As the controls reduced the average temperature of the water in the recirculation loop, the building's internal heat load was reduced. During the heating season, the heating equipment has to supplement some or the entire offset load; in the cooling season, the cooling load may be lower.

The reality of this interaction is complex and difficult to approximate with a model. The extent to which heat lost from the recirculation piping is transferred to conditioned building spaces depends on several factors, including:

- The temperature of the hot water in the loop

- Drafts and infiltration in the pipe chases that communicate with unconditioned air

- The proportion of pipe that travels through unconditioned versus conditioned space within each building

- Differences in pipe diameter/surface area and pipe insulation between unconditioned and conditioned spaces.

The total system efficiencies of the heating and cooling equipment also influence the impact reduced DHW distribution losses will have, as do the typical duration and severity of the local heating and cooling seasons. Some of these factors can be directly measured; however, many others have to be assumed, which increases opportunities for model error. Therefore, the heating penalty and cooling gain calculations used in this study were formulated on the basis of having minimal assumptions. The simple model formed by these assumptions is given in Appendix B.

\subsubsection{Sensitivity Analysis}

Because of the inherent uncertainty in interactivity parameters, a basic sensitivity analysis was conducted to determine the range of impacts interactivity might have on the cost-effectiveness of the DHW controls retrofits. Table 5 outlines the assumptions used for three scenarios: least-, 
middle-, and greatest-effect cases. The range of values selected for each parameter reflect plausible upper and lower bounds given the locations of the test properties, typical building systems found onsite, and otherwise erring conservatively such that the interactive effects are less likely to be underestimated.

Table 5. Space Conditioning Interactivity Modeling Assumptions

\begin{tabular}{c|c|c|c}
\hline Parameter & Least Effect & Middle Case & Greatest Effect \\
\hline Heating Efficiency & $85 \%$ & $75 \%$ & $65 \%$ \\
Heating Hours & 2,686 & 3,263 & 4,074 \\
Cooling Efficiency (Btu/Wh) & 8 & 10 & 12 \\
Cooling Hours & 1,080 & 540 & 540 \\
Percent Interaction & $50 \%$ & $75 \%$ & $100 \%$ \\
\hline
\end{tabular}

Total heating system efficiency assumptions ranged from $85 \%$ to $65 \%$. Annual heating hours were based on average temperature data for New York City (NREL 2005). In the middle case scenario, the total heating hours are accumulated annual hours where outdoor temperature is typically lower than $65^{\circ} \mathrm{F}$ from 6 a.m. to 10 p.m. and lower than $40^{\circ} \mathrm{F}$ from 10 p.m. to 6 a.m. (this corresponds to the temperatures and hours during which, per New York City law, heat must be provided (New York State Legislature 2014a). The least-effect scenario heating hours are the typical annual hours with temperatures that are lower than $50^{\circ} \mathrm{F}$ and $40^{\circ} \mathrm{F}$ for the same day and night periods and the greatest-effect heating hours are the typical annual hours with temperatures that are lower than $55^{\circ} \mathrm{F}$. Assumed cooling equipment efficiency ranged from a seasonal energy efficiency ratio of 8 to 12 . Assumed annual cooling hours ranged from 1,080 in the least-effect case to 540 in the greatest-effect scenario - 90 typical summer days multiplied by 12 and 6 hours, respectively. The team chose 540 hours of annual operation as the middle-case cooling parameter to maintain a conservative estimate of energy savings in the central scenario. Percent interaction was added as a final parameter to estimate the extent to which measured fuel energy savings at the boiler room translated into radiative heat lost into the conditioned areas of the buildings. It was selected to be $50 \%-100 \%$.

\subsubsection{Cost-Effectiveness}

Complete installation costs for the demand recirculation and TM controls, including labor and equipment (controllers, sensors, pumps, and mixing valves, where needed) costs were recorded for each of the four test sites. Annual cost savings were calculated based on DHW fuel and pump electricity reductions and the middle scenario interactive heating penalties and cooling gains attributed to each control strategy. Energy unit costs of $\$ 1.10 /$ therm of natural gas and $\$ 0.20 / \mathrm{kWh}$ were assumed. Simple paybacks for individual test site control strategies as well as the average payback for each control strategy were calculated using the following equation:

\section{Simple Payback $=$ Installed Cost $\div$ Total Annualized Savings}

The range of paybacks generated from the sensitivity analysis was also calculated. Design, consulting, and commissioning fees that may also be incurred as part of DHW control implementation were not included in the analysis; nor were savings that may be incurred from avoided maintenance costs that are due to reduced pump runtime. The useful life of DHW controls is assumed to be 15 years (GTI 2014). 


\subsubsection{Uncertainty Propagation}

Because the fuel use from the monitored control mode periods was normalized against the baseline periods as described in section 2.3.1 above, any systematic inaccuracy in measurements taken of water temperatures and flowrates would affect the final fuel savings calculations. A root-sum-square analysis was applied to the original fuel savings calculations using the published accuracy limitations for the respective dataloggers. The methods are detailed in Appendix A. 


\section{Results}

\subsection{Tenant Comfort}

Interviews were conducted with the buildings' superintendent several times over the course of the test period and surveys were distributed to tenants. The superintendent received no occupant complaints about DHW service. However, several comments in the written surveys indicated confusion and dissatisfaction with the variation in DHW temperature while the TM controls were operating.

\subsection{Recirculation Loop Temperature Reduction}

Table 6 shows the average supply and return temperatures measured and recorded for each DHW control strategy at each site. The building staff maintained the average supply temperature at building higher than the normal safe limits for the entire monitoring period. Demand control at each site in effectively reduced the average return temperature by at least $36^{\circ} \mathrm{F}$ from the average supply temperature; demand controls operated in conjunction with TM at Building B resulted in a $33^{\circ} \mathrm{F}$ reduction.

Table 6. DHW Average System Temperatures (Supply/Return)

\begin{tabular}{c|c|c}
\hline Property & Building A & Building B \\
\hline Baseline & $159^{\circ} \mathrm{F} / 153^{\circ} \mathrm{F}$ & $132^{\circ} \mathrm{F} / 129^{\circ} \mathrm{F}$ \\
Demand Control & $159^{\circ} \mathrm{F} / 77^{\circ} \mathrm{F}$ & $131^{\circ} \mathrm{F} / 95^{\circ} \mathrm{F}$ \\
TM & - & $128^{\circ} \mathrm{F} / 125^{\circ} \mathrm{F}$ \\
Demand Control and TM & - & $129^{\circ} \mathrm{F} / 97^{\circ} \mathrm{F}$ \\
Makeup Water & $48^{\circ} \mathrm{F}$ & $55^{\circ} \mathrm{F}$ \\
\hline
\end{tabular}

When TM controls were active at Building B, average supply and return temperatures were lower than in the baseline case but still higher than expected. Because the TM control was programmed with peak and off-peak set points of $125^{\circ} \mathrm{F}$ and $110^{\circ} \mathrm{F}$, respectively, the supply temperature averages should have fallen somewhere between these set points. The issue was identified by review of the recorded supply temperatures. Figure 8 shows the 5 -minute average temperatures recorded over a 24 -hour period at building B.

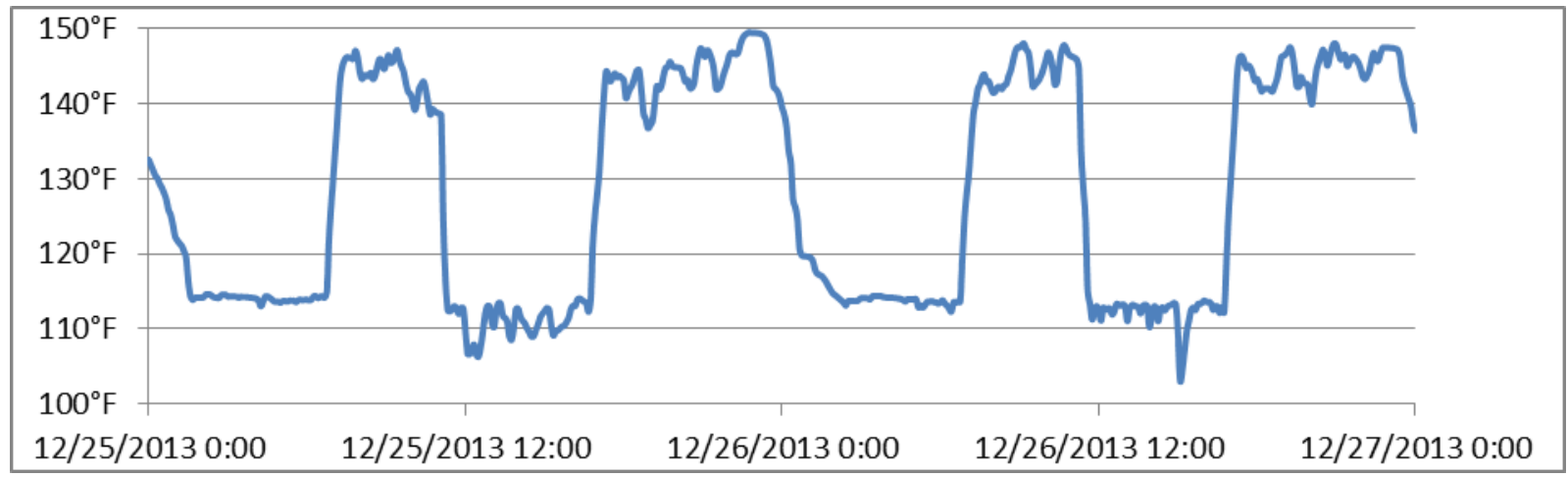

Figure 8. Building B DHW supply temperature in TM mode over a 48-hour period

The storage tank output during TM control off-peak periods was close to the $110^{\circ} \mathrm{F}$ set point, but during peak periods the output was $140^{\circ}-150^{\circ} \mathrm{F}$. At this site the continuous mode average temperature $\left(132^{\circ} \mathrm{F}\right)$ was lower than the TM peak temperatures, making the difference between 
the two modes only $4^{\circ} \mathrm{F}$. This may have also been due to a mis-wiring of the TM control and the storage tank aquastat.

\subsection{Domestic Hot Water Fuel Reduction}

Baseline annualized DHW fuel consumption figures and reductions attributed to each control strategy (given in therms per bedroom and percentage of baseline) are shown in Table 7. Annual baseline consumption was $112-184$ therms per bedroom. DHW fuel use reduction attributed to the control strategies was $6 \%-7 \%$ using demand control, $2 \%$ using TM control, and $15 \%$ using demand and TM controls concurrently. Whether the discrepancy between the sum of fuel reduction from each test strategy alone and the fuel reduction found with both strategies combined reflects measurement error or an actual physical phenomenon is unknown. Although the number of measurement periods employed at building B was small (11 baseline periods, 12 demand control test periods, 5 TM test periods, and 4 demand control combined with TM test periods), both the coefficient of determination values (lowest r-squared recorded: 0.97) and the regression coefficient t-statistic values (lowest recorded: 7.0) suggest that the results of the regression analysis are statistically significant; details are given in Appendix A. Table 8 shows the results of the error propagation analysis.

Table 7. Annualized DHW Fuel Consumption and Reductions per Control Strategy

\begin{tabular}{c|c|c}
\hline Property & Building A & Building B \\
\hline $\begin{array}{c}\text { Annual Baseline DHW } \\
\text { Consumption }\end{array}$ & $\begin{array}{c}184 \text { therms/bedroom; 276 } \\
\text { therms/unit }\end{array}$ & $\begin{array}{c}112 \text { therms/bedroom; 168 } \\
\text { therms/unit }\end{array}$ \\
\hline $\begin{array}{c}\text { DHW Fuel Reduction with } \\
\text { Demand Control }\end{array}$ & $\begin{array}{c}10.3 \text { therms/bedroom; 15.5 } \\
\text { therms/unit (6\%) }\end{array}$ & $\begin{array}{c}8.3 \text { therms/bedroom; 12.5 } \\
\text { therms/unit (7\%) } \\
1.9 \text { therms/bedroom; 2.9 } \\
\text { therms/unit (2\%) }\end{array}$ \\
$\begin{array}{c}\text { DHW Fuel Reduction with TM } \\
\text { DHW Fuel Reduction with } \\
\text { Demand Control and TM }\end{array}$ & - & $\begin{array}{c}16.2 \text { therms/bedroom; 24.3 } \\
\text { therms/unit (15\%) }\end{array}$ \\
\hline
\end{tabular}

Table 8. Annualized Fuel Reduction Propagated Measurement Uncertainty

\begin{tabular}{c|c|c}
\hline Property & Building A & Building B \\
\hline DHW Fuel Reduction with Demand Control & $\pm 1.9 \%$ & $\pm 3.9 \%$ \\
DHW Fuel Reduction with TM & - & $\pm 3.9 \%$ \\
DHW Fuel Reduction with Demand Control and TM & - & $\pm 4.0 \%$ \\
\hline
\end{tabular}

\subsection{Recirculation Pump Runtime Reduction}

Recirculation pump runtime reductions exceeded $99 \%$ at both properties. Recorded average runtime was only 1 minute per day at building $\mathrm{A}$, and 14 minutes per day at building $\mathrm{B}$. This is a $99 \%$ reduction from continuous use. The shorter runtime at building A was concluded to be a result of the excessively high supply temperature $\left(159^{\circ} \mathrm{F}\right.$, on average leaving the storage tanks at that site, an issue the boiler service contractor was not able to resolve during the monitoring period. The subsequent annualized reduction in pump electricity use at each property fell 1,709$1,725 \mathrm{kWh}$ (Table 8 ) as a result of the demand controls. 
Table 9. Recirculation Pump Savings with Demand Control

\begin{tabular}{c|c|c}
\hline Property & Building A & Building B \\
\hline Recirculation Pump Power & 197 watts & 197 watts \\
Pump Runtime with Demand Control & $1 \mathrm{~min} /$ day & $14 \mathrm{~min} /$ day \\
Annual Pump kWh Reduction & $1,725 \mathrm{kWh}$ & $1,709 \mathrm{kWh}$ \\
\hline
\end{tabular}

\subsection{Interactivity with Space Conditioning}

Using the "middle scenario" interactivity assumptions, calculated per-bedroom and per-unit heating fuel penalties (in therms of natural gas) and cooling electricity reductions (kWh) for each control strategy are given in Table 9 . The projected heating penalty is $37 \%$ of the measured DHW fuel reduction attributed to the control strategy employed. On a cost basis (cost savings are shown in the following section), cooling electricity reduction contributed $8 \%-9 \%$ of the total annualized cost savings that were attributed to DHW control implementation.

Table 10. Calculated Annual Heating and Cooling Interaction for DHW Controls

\begin{tabular}{|c|c|c|}
\hline Property & Building A & Building B \\
\hline $\begin{array}{l}\text { Demand Control Cooling } \\
\text { Reduction }\end{array}$ & $\begin{array}{l}6.4 \mathrm{kWh} / \text { bedroom; } \\
9.6 \mathrm{kWh} / \text { unit }\end{array}$ & $\begin{array}{l}5.1 \mathrm{kWh} / \text { bedroom; } \\
7.7 \mathrm{kWh} / \text { unit }\end{array}$ \\
\hline $\begin{array}{c}\text { Demand Control Heating } \\
\text { Penalty }\end{array}$ & $\begin{array}{l}3.8 \text { therms/bedroom; } \\
5.7 \text { therms/unit }\end{array}$ & $\begin{array}{l}3.1 \text { therms/bedroom; } \\
4.7 \text { therms/unit }\end{array}$ \\
\hline TM Cooling Reduction & - & $\begin{array}{c}1.1 \mathrm{kWh} / \text { bedroom; } \\
1.7 \mathrm{kWh} / \text { unit }\end{array}$ \\
\hline TM Heating Penalty & - & $\begin{array}{l}0.7 \text { therms/bedroom; } \\
1.1 \text { therms/unit }\end{array}$ \\
\hline $\begin{array}{l}\text { Demand Control and TM } \\
\text { Cooling Reduction }\end{array}$ & - & $\begin{array}{l}10 \mathrm{kWh} / \text { bedroom; } \\
15 \mathrm{kWh} / \text { unit }\end{array}$ \\
\hline $\begin{array}{c}\text { Demand Control and TM } \\
\text { Heating Penalty }\end{array}$ & - & $\begin{array}{l}6.0 \text { therms/bedroom; } \\
9.0 \text { therms/unit }\end{array}$ \\
\hline
\end{tabular}

\subsection{Cost Savings and Payback}

Table 10 shows annualized per-bedroom and per-unit baseline DHW costs for each site. These baseline costs include the costs of the DHW fuel and the recirculation pump electricity (at assumed unit rates of $\$ 1.10 /$ therm of natural gas and $\$ 0.20 / \mathrm{kWh}$ ). The annualized savings shown are calculated to include DHW fuel and pump electricity reductions as well as interactive cooling and heating costs, per the "middle scenario" interactivity assumptions.

Table 11 shows total annual DHW costs, actual installation costs, and the calculated simple paybacks for each control strategy at each site. Annual building wide DHW costs were $\$ 9,200$ $\$ 31,200$. Retrofit implementation cost was $\$ 3,000$ for demand control and $\$ 2,000$ for TM control. Simple payback was 3-3.7 years for demand control only; it was 18.5 years for TM only at building $\mathrm{B}$, and 4 years for demand and TM controls together at building $\mathrm{B}$. 
Table 11. Annualized Total per-Bedroom DHW Costs and

Savings with Space Conditioning Interactivity Applied

\begin{tabular}{|c|c|c|}
\hline Property & Building A & Building B \\
\hline Baseline DHW Consumption & \$207/bedroom; \$310/unit & \$128/bedroom; \$192/unit \\
\hline Demand Control Savings & $\begin{array}{c}\$ 12.30 / \text { bedroom; } \$ 18.50 / \text { unit } \\
(6 \%)\end{array}$ & $\begin{array}{c}\text { \$11.20/bedroom; } \$ 16.80 / \text { unit } \\
(9 \%)\end{array}$ \\
\hline TM Savings & - & $\begin{array}{c}\text { \$1.50/bedroom; } \$ 2.30 / \text { unit } \\
(1 \%)\end{array}$ \\
\hline $\begin{array}{c}\text { Demand Control and TM } \\
\text { Savings }\end{array}$ & - & $\begin{array}{c}\$ 17.30 / \text { bedroom; } \$ 26 / \text { unit } \\
(14 \%)\end{array}$ \\
\hline
\end{tabular}

Table 12. Total Annual Baseline DHW Costs, Installed Control Costs, and Simple Payback per Control Strategy

\begin{tabular}{c|c|c}
\hline Property & Building A & Building B \\
\hline Annual DHW Cost (Including & $\$ 16,800$ & $\$ 9,200$ \\
Recirculation Pump Electricity) & $\$ 3,000$ & $\$ 3,000 / \$ 2,000$ \\
Installed Cost of Demand/TM Controls & 3.0 years & 3.7 years \\
Demand Control Payback & - & 18.5 years \\
TM Payback & - & 4.0 years \\
\hline
\end{tabular}

\subsubsection{Sensitivity Analysis}

Table 12 shows the range of simple paybacks (in years) for the DHW control methods implemented at each building and calculated using the "least-effect" and "greatest-effect" interactivity assumptions. The same per-unit natural gas and electricity rates and the actual initial costs were used. On average, calculated space-conditioning interactive effects for the least-effect scenario decreased annual cost savings by $27 \%$; interactive effects calculated for the greatesteffect scenario increased annual cost savings by $37 \%$. This extended the range of simple paybacks from 2.4 to 5.1 years for demand control, 14 to 36 years for TM, and 3.2 to 6.1 years for demand control and TM together.

Table 13. Years Simple Payback Calculated for Sensitivity Analysis of Interactive Effects

\begin{tabular}{c|c|c|c|c}
\hline Property & \multicolumn{2}{|c|}{ Building A } & \multicolumn{2}{c}{ Building B } \\
\hline DHW Control & Least effect & Greatest effect & Least effect & Greatest effect \\
Demand Control & 2.4 & 4.3 & 3.1 & 5.1 \\
TM & - & - & 14 & 36 \\
\hline Demand Control and TM & - & - & 3.2 & 6.1 \\
\hline
\end{tabular}

\subsection{Other Results}

\subsubsection{Seasonal Patterns}

Figure 6 appears to show a trend of greater winter per-capita DHW consumption compared to summer use at both buildings. Figure 9 shows the general correlation of decreasing makeup water temperature to increasing boiler runtime at building $\mathrm{B}$. 

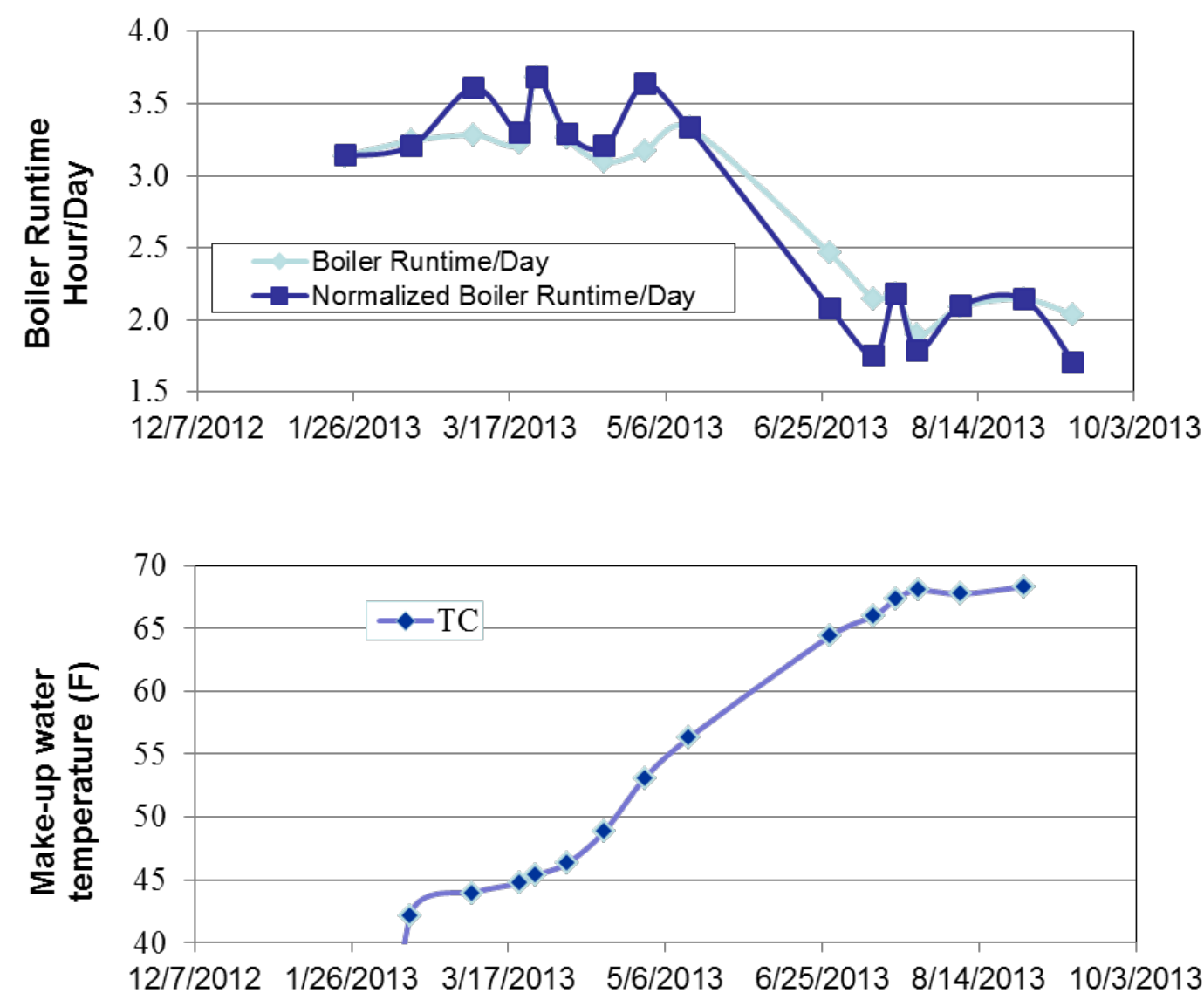

Figure 9. Seasonal variations in boiler runtime and makeup water temperature at building B

\subsubsection{Daily Draw Patterns}

The collection of graphs in Figure 10 gives a sample of typical 24-hour DHW flow rates for each test site. Weekdays and weekend days are included. Peaks and troughs are observable but occur to a much lesser degree than was anticipated. Periods of low/no-flow can be seen in the late evening hours on each graph, but are inconsistent in onset and duration. Morning and afternoon peaks are similarly inconsistent, and in some cases the highest DHW use occurs during the early afternoon, matching poorly in comparison to the on-peak/off-peak schedule (Figure 4) used for TM control mode. 

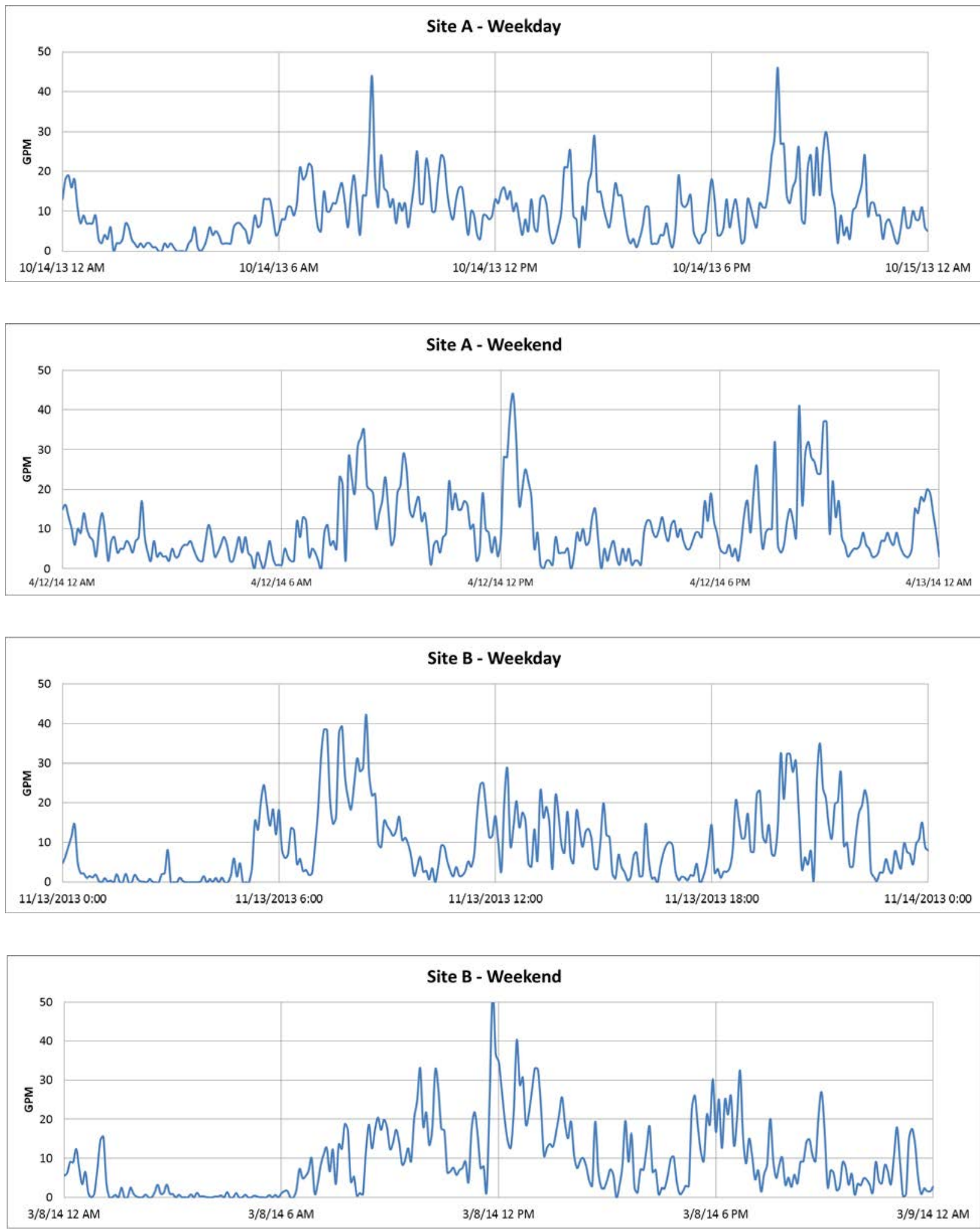

Figure 10. Collection of typical 24-hour DHW flow rates from test sites A and B 


\section{Discussion and Conclusion}

\subsection{Answers to Research Questions}

1. How do DHW control strategies compare to the baseline case and to each other in terms of energy savings?

The results of the monitoring and analysis of DHW controls in this study show that savings were achieved with each control strategy at each test site compared with the baseline case. Demand recirculation control was more effective than TM, and the combination of the two strategies was the most effective control regime. Percent DHW fuel energy reductions from the baseline case were $6 \%-7 \%$ for demand recirculation, $2 \%$ for $\mathrm{TM}$, and $15 \%$ for demand recirculation and $\mathrm{TM}$ controls implemented together.

Recirculation pump runtime reduction under demand control was also significant at each test site, resulting in a $99 \%$ or greater reduction in pump electricity use.

2. What is the cost-effectiveness of the DHW control system retrofits?

Demand recirculation and demand recirculation combined with TM controls were cost-effective retrofits for both test buildings; however, the TM control retrofit alone was not cost-effective at the one site where it was implemented. Several factors affect the extent to which these results can or cannot be generalized to other properties: property size, cost of implementation, fuel type, and utility rate.

Although the total DHW consumption and attendant control savings generally scale with the number of building occupants, installation costs are more or less fixed per system. This means that larger buildings and buildings with greater per-capita DHW use tend to exhibit greater costeffectiveness and shorter simple payback, as this study sample showed. Moreover, the labor rates charged for the DHW control installations at the test sites may have been inflated because the plumber was unfamiliar with these controls, which are current rarity in the New York market. By comparison, the cost for demand recirculation control installation in California is $\$ 600$ for labor and \$1,500 for equipment (Bender and Kosar 2013).

Natural gas was the DHW fuel in both buildings. Natural gas has the lowest cost per Btu among the fuels commonly used in multifamily and commercial buildings. If a more expensive fuel such as electricity or oil were being used, the payback would be shorter. Additional savings from avoided maintenance costs were not included in the analysis. In practice, reduced recirculation pump runtime could extend the life of the pump and increase the cost-effectiveness of DHW control retrofits.

3. How do interactive effects between DHW energy savings and the heating/cooling loads affect the cost-effectiveness of DHW control retrofits?

Applying interactive effects had a negative impact on both the annual cost savings and simple payback because New York has a heating-dominated climate and the additional cost of the natural gas heating outweighed the reduced cooling electricity costs per the interactivity model. The central scenario lengthens the payback period by an average of $23 \%$ compared with the paybacks with no space-conditioning interactivity. With the greatest-effect scenario interactivity assumptions applied, the longest payback for demand recirculation control was 5.1 years, and the 
longest payback for demand recirculation combined with TM control was 6.1 years. For TM control implemented alone however, the longest payback was 36 years, far exceeding the 15 -year assumed useful life of DHW controls.

\subsection{Comparison with Earlier Studies}

Although the DHW fuel savings attributed to demand controls in earlier research were 5\%-44\% (median 16\%), 7\% was the average from the two buildings tested in this study before the interactive effects were considered. TM savings were $2 \%$ compared to the $35 \%$ found at a single building in California, but the control strategy and monitoring approach were not discussed in detail in that study. The $15 \%$ average DHW fuel reduction from the combined demand and TM controls at building B comes closer to the median savings previously reported for demand controls. At least in some cases, some of the total savings cited in earlier research may have included the effects of DHW system commissioning as a byproduct of the control retrofits, e.g., lowering the supply temperature and recirculation pumping rate by some amount, and in turn incurring additional savings beyond what was more stringently accounted for in this study. Additionally, the pipe insulation along the entire recirculation loop, which is more common in newer buildings and was the case with the two buildings studied here, should improve initial DHW system efficiency and provide less opportunity for savings through demand and TM control installation.

\subsection{Domestic Hot Water Control Optimization}

The $110^{\circ} \mathrm{F}$ supply temperature water that leaves the DHW plant was apparently sufficient to maintain occupant comfort at building B. Daily DHW use did not have regular peak and off-peak use trends and no complaints of discomfort were made during the lower temperature period of the TM mode over the length of the study. These facts appear to point to an optimal-efficiency strategy in which a constant lower temperature DHW is supplied in conjunction with demand control of the recirculation pump. This would also minimize the initial costs by not including TM control installation.

\subsection{Importance of Commissioning Domestic Hot Water Systems}

The importance of commissioning control retrofits was underscored by the TM problems that occurred at building B. The TM control did not reduce the supply temperature as intended, so savings were lower than optimal and the payback was longer. For building A, at elevated temperatures the same degree reduction will result in greater radiative heat loss reduction recirculation loop piping; however, the end goal of a property owner is to increase efficiency and maximize savings. If a given property has elevated DHW supply temperature, the opportunity should certainly be taken to reduce this temperature as much as possible by properly commissioning DHW boiler set points and other aspects of the DHW system in conjunction with the retrofitted controls.

\subsection{Other Findings}

Building scientists acknowledge seasonal variations in makeup water temperature and per-capita water use, but available literature that formally documents these trends is limited. Measured data as shown in Figure 6 and Figure 7 may prove useful for other energy-efficiency research and tool development. 


\subsection{Potential for Legionella Contamination}

DHW systems can be susceptible to contamination with Legionella bacteria because temperatures of $77^{\circ}-108^{\circ} \mathrm{F}$ can provide favorable conditions for the growth of these bacteria (ASHRAE 2000). The Occupational Safety and Health Administration discourages the use of demand recirculation control specifically out of concern for potential contamination of DHW systems with Legionella bacteria and recommends a constant minimum water temperature of $122^{\circ} \mathrm{F}$ throughout all DHW piping (OSHA 2014). This guidance conflicts with other government agency recommendations and requirements. The ENERGY STAR ${ }^{\circledR}$ program recommends demand recirculation (EPA and DOE 2014); California building code currently requires the use of demand recirculation controls in newly constructed multifamily buildings (CEC 2012); New York City building code currently allows a minimum DHW discharge temperature of $110^{\circ} \mathrm{F}$ in buildings equipped with mixing valves (New York State Legislature 2014b). Alternative means of preventing Legionella in DHW systems are at various stages of development, implementation, and research. "Dead leg" sections of domestic water piping where water can remain stagnant are highlighted as the most likely places for Legionella to grow, and more research is needed to determine whether the frequent exchange of water in DHW recirculation loops places them at lower risk for bacterial establishment.

\subsection{Future Research}

\subsubsection{Modeling Space Conditioning Interactivity in Different Climates}

To extend the generalizability of the interactive-effect calculations performed in this study, interactivity could be modeled for several different climates. This would allow breakeven points to be identified beyond which the amount of avoided cooling would completely offset the heating penalty cost and result in a net financial gain of interactive effects.

\subsubsection{Demand Recirculation Controls with Electronic and Mechanical Mixing Valves}

A major market barrier to wider implementation of DHW demand control retrofits is the prevalence of tankless mixing valve DHW systems (where a DHW coil passes through the spaceheating boiler and feeds into a tempering valve) and a perceived lack of demand recirculation control-compatible with DHW mixing valves. Several of the most commonly found tempering valves installed in tankless DHW systems require continuous flow for one of three reasons given by manufacturers:

- Frequent, rapid transition from cool, stagnant water temperatures to hot boiler water temperatures can overstress the mechanical bellows in thermostatic mixing valves and lead to early failure.

- Un-tempered hot water at rest in the pipe that supplies the mixing valve can still contribute too much heat to the valve body and stress the internal components.

- Under-dampened "hunting" behavior in electronic valves can occur momentarily when flow is resumed and cause a slug of hot un-tempered boiler water to enter the supply line.

These issues may cause unsafe water temperatures at the tap. Appendix D provides a list of approved and unapproved mixing valve makes and models for use with non-continuous DHW recirculation. Research is needed to document the performance of mixing valves that are approved for use with demand controls, and perhaps also to develop plumbing details that would 
allow existing mixing valves to work consistently with demand controls. A second, smaller recirculation loop in the boiler room may ensure constant flow with negligible energy losses.

\subsubsection{Effects of Demand Control on Tank Stratification and Associated Capacity and Safety Issues}

DHW storage tank temperature stratification may be intensified by demand recirculation controls (Gifford 2004). Temperature stratification within storage tanks is caused by the difference in density between the hotter, less dense water supplied to the tank by the boiler and cold, denser makeup water supplied to the tank from the municipal water main. Under conditions of continuous DHW recirculation with typical storage tank installations, some degree of mixing can be expected as the recirculation water is drawn through the tank supply tapping at the top of the tank and returned to the tank's bottom section (where cold makeup water also enters). The degree to which the tank water temperature is homogenized by the mixing effect of the recirculation water depends on tank aspect ratio, recirculation pump horsepower, the speed and flow rate of the recirculation water, and so on. Gifford's research describes an optimal but not easily quantified balance between desirable system effects gained from some levels of stratification and mixing; temperature stratification effectively increases the output of hot water (fed from the upper area) of the tank, and some mixing of the tank contents prevent un-tempered hot water from short-circuiting across the top of the tank from the boiler inlet tapping to the building supply pipe. Therefore, scalding water could be sent to faucets and showerheads when demand controls stop recirculation pumping for periods of time. Further research should identify the prevalence of unintended, unsafe temperature supply spikes across different indirect-fired DHW storage tank installations. Similar to the potential solution proposed for mixing valve flow requirements, perhaps a low-energy pump and short piping loop could allow demand controls to operate safely if over-stratification remains a concern.

\subsubsection{Effects of Crossover on Demand Recirculation Controls}

Crossover is the unintended flow of water from the cold side of the domestic water piping to the DHW piping, or vice versa, and takes place at worn faucet mixing cartridges and washing machine and dishwasher appliance connections to the pipe network. The prevalence and magnitude of this issue are unknown, but several recent studies have identified crossover in a number of buildings (McNamara et al. 2011; Bright Power, Inc. 2014; EDC Technologies, Inc. 2009; Sachs et al. 2001). Crossover is a potential barrier to recirculation control implementation because cold water entering the recirculation piping may lower the temperature at the return piping thermostat, leading to excessive recirculation pump runtime and reducing the costeffectiveness of the measure. Crossover may also lead to occupant complaints, which may cause building staff to deactivate controls. Research is needed that will quantify the energy impacts of crossover on demand recirculation controls and identify cost-effective retrofits to remedy this problem. 


\section{References}

ASHRAE. (2000). ASHRAE Guideline 12-2000. Atlanta: American Society of Heating, Refrigerating and Air-Conditioning Engineers, Inc.

Bender, T., and Kosar, D. 2013. Demand-Based Domestic Hot Water Recirculation: Public Project Report. Naperville, IL: Nicor Gas Efficiency Emerging Technology Program.

Benningfield Group. 2008. New Pumping Technology Saves Energy and Money: Case Study on Demand Efficiency.

Benningfield Group. 2009. Demand Control for Multifamily Central Domestic Hot Water.

Bright Power, Inc. 2014. Investigation of a Simplified Method for Detecting Rogue Bypass in Buildings with CHP and Solar Thermal Preheat Systems. Albany, NY: New York State Energy Research and Development Authority.

California Utilities Statewide Codes and Standards Team. 2011. Multifamily Central DHW and Solar Water Heating: 2013 California Building Energy Efficiency Standards. California Public Utilities Commission.

CEC. 2012. "California Code of Regulations Title 24 §150.1(c)8. n.d.” 2013 Building Energy Efficiency Standards for Residential and Nonresidential Buildings. California Energy Commission: http://www.energy.ca.gov/2012publications/CEC-400-2012-004/CEC-400-2012004-CMF-REV2.pdf.

Dinse, D.R., and Henderson, H.I. 2004. Field Performance of HPWH Preheating for Water Heating Systems in Schools. ASHRAE Transactions, 690.

EDC Technologies, Inc. 2009. "Cross Over Historical Analysis: The Effect on Energy Efficiency and Hot Water System Operation." ACEEE 2009 Hot Water Forum. Pacific Grove, CA.

Enovative Systems. 2008. Oxford Club Apartments: Case Study.

Enovative Systems. 2009. William Penn Apartments: Case Study. Los Angeles, CA.

Enovative Systems. 2010a. Welk Resorts: Case Study. Escondido, CA.

Enovative Systems. 2010b. Equity Residential: Case Study. Irvine, CA.

Enovative Systems. 2011a. Pepperdine University: Case Study. Malibu, CA.

EPA and DOE. 2014. Demand Hot Water Recirculating System. ENERGY STAR, accessed December 3, 2014: https://www.energystar.gov/index.cfm?c=water_heat.pr_demand_hot_water.

Gifford, H. 2004. "Indirect Water Heater Mixing and Control.” HPAC Engineering, pp. 55-62.

Goldner, F. 1999. DHW Modeling: System Sizing and Selection Criteria, A Study of Baseloads and Seasonal Efficiency. Final Report 99-2. Albany, NY: New York State Energy Research and Development Authority. 
GTI. 2014. On-Demand Controls for Central Hot Water Systems White Paper. Des Plaines, IL: Gas Technology Institute.

HMG 2010. "Central Domestic Hot Water Systems in Multi-Family Buildings.” ACEEE 2010 Hot Water Forum. Sacramento, CA: Heschong Mahone Group.

Levy Partnership. Forthcoming. Energy-Efficient Controls for Multifamily Domestic Hot Water Systems. Albany, NY: New York State Energy Research and Development Authority.

Lutz, J.D. 2008. Water Heaters and Hot Water Distribution Systems. CEC-500-2005-007:

California Energy Commission, PIER Buildings End-Use Energy Efficiency.

McNamara, A., Gruen, S. Laver, C., and Perlman, J. 2011. The Negative Impact of Cold Water Bypass on Solar Domestic Hot Water Systems. Albany, NY: New York State Energy Research and Development Authority.

New York State Legislature. 2014a. New York City Administrative Code §27-2029. Retrieved December 3, 2014, from Laws of New York: http://public.leginfo.state.ny.us.

New York State Legislature. 2014b. New York City Administrative Code §27-2031. Retrieved December 3, 2014, from Laws of New York: http://public.leginfo.state.ny.us.

NREL. 2005. 1991- 2005 Update: Typical Meteorological Year 3. Accessed December 9, 2014: National Solar Radiation Data Base: http://rredc.nrel.gov/solar/old_data/nsrdb/19912005/tmy3/by_state_and_city.html\#N.

NREL. 2012. Building America Critical Path Milestones. Golden, CO: National Renewable Energy Laboratory.

OSHA. 2014. Legionnaires' Disease. Occupational Safety and Health Administration, accessed December 11, 2014: https:/www.osha.gov/dts/osta/otm/legionnaires/hotwater.html.

Sachs, H., Talbot, J., and Kaufman, N. 2011. Emerging Hot Water Technologies and Practices for Energy Efficiency. Washington, DC: American Council for an Energy Efficient Economy.

Sempra Energy. 2010. "Central Domestic Hot Water Systems in Multi-Family Buildings." ACEEE 2010 Hot Water Forum.

Wendt, R., Baskin, E., and Durfee, D. 2004. Evaluation of Residential Hot Water Distribution Systems by Numeric Simulation. Agreement ERD-01-2048 and Energy Commission Contract No: 400-00-038. Oak Ridge, TN: Oak Ridge National Laboratory.

Zobrist, D. (2010). ACEEE Hot Water Forum. Ontario, CA. 


\section{Appendix A. Domestic Hot Water Energy Use Calculations \\ Domestic Hot Water Fuel Usage Calculations}

$$
\text { Total DHW Fuel }=\text { Runtime } \times \text { Firing Rate }
$$

Where

Total DHW Fuel is in units of therms

Firing Rate is the average of several spot measurements:

$$
\text { Firing Rate }=\frac{C C F_{\text {gas }}}{\text { Runtime }_{B}} \times 1.03
$$

Runtime is the datalogger recorded DHW boiler runtime, in total hours per test period.

Firing Rate is in units of therms per hour

$C C F_{\text {gas }}$ is the recorded DHW natural gas consumption, in hundred cubic feet

Runtime $_{B}$ is the boiler runtime recorded over the same interval as the gas meter reading, in hours

1.03 is the conversion factor, in therms/hundred cubic feet

NB: For test buildings with multiple DHW boilers and/or dual firing rates, runtime for each boiler at each firing rate was recorded, and average fuel consumption for each firing rate was also measured. 


\section{Domestic Hot Water Fuel Usage Normalization and Annualized Reduction Calculations Method I (Building A):}

$$
\begin{aligned}
& \text { Total DHW Fuel } \text { norm }_{\text {}} \\
& =\text { Total DHW Fuel }_{\text {Test }} \times \frac{\text { Total Flow }_{\text {Base }}}{\text { Total Flow }} \\
& \times \frac{\left(T_{\text {Supply Base }}-T_{\text {Makeup Base }}\right)}{\left(T_{\text {Supply Test }}-T_{\text {Makeup Test }}\right)}
\end{aligned}
$$

Where

Total Flow Base $_{\text {is }}$ the total recorded DHW makeup water volume for the nearest baseline period, in gallons

Total Flow Test $_{\text {is }}$ the total recorded DHW makeup water volume for the test period to be normalized, in gallons

$T_{\text {Supply Base }}$ is the average recorded DHW supply temperature for the nearest baseline period, in degrees Fahrenheit

$T_{\text {Makeup Base }}$ is the average recorded cold mains makeup water temperature for the nearest baseline period, in degrees Fahrenheit

$T_{\text {Supply Test }}$ is the average recorded DHW supply temperature for the test period to be normalized, in degrees Fahrenheit

$T_{\text {Makeup Test }}$ is the average recorded cold mains makeup water temperature for the test period to be normalized, in degrees Fahrenheit

\section{Average Annualized DHW Fuel Reduction}

$$
=\frac{\sum \text { Daily DHW Reduction }_{1} \times \text { Period }_{\text {Test }_{1}}+\text { Daily DHW Reduction }_{2} \times \text { Period }_{\text {Test }_{2}} \cdots}{\sum \text { Period }_{\text {Test }_{1}}+\text { Period }_{\text {Test }_{2}} \cdots}
$$

$\times 365$

Where

$$
\begin{aligned}
& \text { Daily DHW Reduction } \\
& \quad=(\text { Total DHW Fuel } \\
& -(\text { Total DHW Fuel } \\
& \left.- \text { Period }_{\text {Base }}\right)
\end{aligned}
$$

Period $_{\text {Test }}$ is a given 1- to 3-week test period for a DHW control strategy, in days

Period $_{\text {Base }}$ is the temporally closest baseline mode period, in days 


\section{Method II (Building B):}

Because the TM test periods were not evenly alternated across seasons at this site, test period daily DHW fuel usage figures were regressed against the corresponding DHW volumes and $\Delta$ Ts (DHW supply temperature less the makeup water temperature) by multiple linear regression analysis to obtain linear coefficients that were applied to the baseline period consumption to obtain normalized test period fuel usage. The percent reduction in fuel consumption for each baseline and normalized period was recorded, and the average reduction for each DHW control strategy was used to calculate annualized fuel savings.

Step 1. Daily DHW fuel use, DHW volume (GPD), and $\Delta T$ were tabulated for each baseline and test period:

Table 14. Building B Monitoring Period Profile Data

\begin{tabular}{|c|c|c|c|c|}
\hline Control & End Date & Therms/Day & GPD & $\Delta \mathrm{T}\left({ }^{\circ} \mathbf{F}\right)$ \\
\hline Baseline & $8 / 25 / 2013$ & 15 & 2288 & 57 \\
\hline Baseline & $9 / 8 / 2013$ & 16 & 2494 & 57 \\
\hline Baseline & $9 / 22 / 2013$ & 17 & 2544 & 59 \\
\hline Baseline & 10/6/2013 & 16 & 2396 & 60 \\
\hline Baseline & $10 / 20 / 2013$ & 18 & 2564 & 62 \\
\hline Baseline & $11 / 3 / 2013$ & 19 & 2516 & 66 \\
\hline Baseline & $11 / 17 / 2013$ & 21 & 2654 & 71 \\
\hline Baseline & $12 / 1 / 2013$ & 25 & 2924 & 76 \\
\hline Baseline & $12 / 15 / 2013$ & 27 & 3023 & 79 \\
\hline Baseline & $3 / 9 / 2014$ & 37 & 2970 & 104 \\
\hline Baseline & $3 / 21 / 2014$ & 34 & 3057 & 102 \\
\hline Demand & 8/18/2013 & 14 & 2300 & 58 \\
\hline Demand & $9 / 1 / 2013$ & 15 & 2576 & 57 \\
\hline Demand & $9 / 15 / 2013$ & 18 & 3055 & 57 \\
\hline Demand & 9/29/2013 & 17 & 2711 & 59 \\
\hline Demand & $10 / 13 / 2013$ & 17 & 2750 & 60 \\
\hline Demand & $10 / 27 / 2013$ & 18 & 2757 & 63 \\
\hline Demand & $11 / 10 / 2013$ & 21 & 2972 & 68 \\
\hline Demand & $11 / 24 / 2013$ & 22 & 2922 & 72 \\
\hline Demand & $12 / 8 / 2013$ & 24 & 2985 & 77 \\
\hline Demand & $12 / 22 / 2013$ & 27 & 3171 & 81 \\
\hline Demand & $3 / 2 / 2014$ & 35 & 3352 & 104 \\
\hline Demand & $3 / 16 / 2014$ & 34 & 3327 & 102 \\
\hline TM & $12 / 29 / 2013$ & 27 & 2933 & 82 \\
\hline TM & $1 / 12 / 2014$ & 32 & 3375 & 84 \\
\hline TM & $1 / 26 / 2014$ & 30 & 3073 & 86 \\
\hline TM & $2 / 9 / 2014$ & 31 & 3242 & 87 \\
\hline TM & $2 / 21 / 2014$ & 32 & 3129 & 91 \\
\hline TM and Demand & $1 / 5 / 2014$ & 31 & 3535 & 84 \\
\hline TM and Demand & $1 / 19 / 2014$ & 30 & 3282 & 88 \\
\hline TM and Demand & $2 / 2 / 2014$ & 33 & 3624 & 89 \\
\hline TM and Demand & $2 / 16 / 2014$ & 33 & 3498 & 91 \\
\hline
\end{tabular}


Step 2. Multilinear regression was done in Microsoft Excel using DHW fuel usage as the dependent variable and both $\mathrm{DHW}$ volume and $\Delta \mathrm{T}$ as independent variables: 
Table 15. Multilinear Regression Analysis

\begin{tabular}{|c|c|c|c|c|c|c|c|c|}
\hline \multicolumn{9}{|c|}{ SUMMARY OUTPUT - Demand } \\
\hline \multicolumn{9}{|c|}{ Regression Statistics } \\
\hline Multiple R & 0.9998683 & & & & & & & \\
\hline R Square & 0.9997367 & & & & & & & \\
\hline Adjusted R Square & 0.9996781 & & & & & & & \\
\hline Standard Error & 0.1248245 & & & & & & & \\
\hline Observations & 12 & & & & & & & \\
\hline \multicolumn{9}{|l|}{ ANOVA } \\
\hline & df & SS & MS & $\mathrm{F}$ & Significance F & & & \\
\hline Regression & 2 & 532.36199 & 266.181 & 17083.534 & $7.804 \mathrm{E}-17$ & & & \\
\hline Residual & 9 & 0.1402303 & 0.0155811 & & & & & \\
\hline Total & 11 & 532.50222 & & & & & & \\
\hline Demand & Coefficients & Standard Error & t Stat & P-value & Lower 95\% & Upper 95\% & Lower 95\% & Upper 95\% \\
\hline Intercept & -18.057387 & 0.4233905 & -42.64949 & $1.069 \mathrm{E}-11$ & -19.015163 & -17.099612 & -19.015163 & -17.099612 \\
\hline GPD & 0.005678 & 0.0002133 & 26.624858 & 7.192E-10 & 0.0051955 & 0.0061604 & 0.0051955 & 0.0061604 \\
\hline$\Delta T$ & 0.3265523 & 0.0039217 & 83.26781 & $2.632 \mathrm{E}-14$ & 0.3176808 & 0.3354238 & 0.3176808 & 0.3354238 \\
\hline \multicolumn{9}{|c|}{ SUMMARY OUTPUT- TM } \\
\hline \multicolumn{9}{|c|}{ Regression Statistics } \\
\hline Multiple R & 0.9937388 & & & & & & & \\
\hline R Square & 0.9875167 & & & & & & & \\
\hline Adjusted R Square & 0.9750335 & & & & & & & \\
\hline Standard Error & 0.303568 & & & & & & & \\
\hline Observations & 5 & & & & & & & \\
\hline \multicolumn{9}{|l|}{ ANOVA } \\
\hline & df & SS & MS & $\mathrm{F}$ & Significance F & & & \\
\hline Regression & 2 & 14.58004 & 7.2900202 & 79.107326 & 0.0124833 & & & \\
\hline Residual & 2 & 0.1843071 & 0.0921535 & & & & & \\
\hline Total & 4 & 14.764347 & & & & & & \\
\hline TM & Coefficients & Standard Error & t Stat & P-value & Lower 95\% & Upper $95 \%$ & Lower $95.0 \%$ & Upper $95.0 \%$ \\
\hline Intercept & -23.126572 & 4.4383456 & -5.210629 & 0.034914 & -42.223232 & -4.0299126 & -42.223232 & -4.0299126 \\
\hline GPD & 0.007915 & 0.0009314 & 8.4981157 & 0.0135658 & 0.0039076 & 0.0119225 & 0.0039076 & 0.0119225 \\
\hline
\end{tabular}


U.s. Department of Energy Efficiency \&

ENERGY Renewable Energy

\begin{tabular}{|c|c|c|c|c|c|c|c|c|}
\hline \multirow[t]{2}{*}{$\Delta \mathrm{T}$} & 0.3325049 & 0.0474882 & 7.0018467 & 0.0197938 & 0.1281798 & 0.5368299 & 0.1281798 & 0.5368299 \\
\hline & \multicolumn{8}{|c|}{ SUMMARY OUTPUT - Demand and TM } \\
\hline \multicolumn{9}{|c|}{ Regression Statistics } \\
\hline Multiple R & 0.99791 & & & & & & & \\
\hline R Square & 0.9958243 & & & & & & & \\
\hline Adjusted R Square & 0.987473 & & & & & & & \\
\hline Standard Error & 0.1823765 & & & & & & & \\
\hline Observations & 4 & & & & & & & \\
\hline \multicolumn{9}{|l|}{ ANOVA } \\
\hline & df & $\mathrm{SS}$ & MS & $\mathrm{F}$ & Significance F & & & \\
\hline Regression & 2 & 7.9322327 & 3.9661164 & 119.24153 & 0.0646194 & & & \\
\hline Residual & 1 & 0.0332612 & 0.0332612 & & & & & \\
\hline Total & 3 & 7.9654939 & & & & & & \\
\hline TM and Demand & Coefficients & Standard Error & t Stat & $\mathrm{P}$-value & Lower 95\% & Upper 95\% & Lower 95\% & Upper 95\% \\
\hline Intercept & -28.813486 & 4.0417376 & -7.1289849 & 0.0887213 & -80.168632 & 22.541659 & -80.168632 & 22.541659 \\
\hline GPD & 0.0090104 & 0.0007267 & 12.399699 & 0.0512307 & -0.0002227 & 0.0182436 & -0.0002227 & 0.0182436 \\
\hline$\Delta \mathrm{T}$ & 0.3352537 & 0.0347808 & 9.6390537 & 0.0658104 & -0.1066779 & 0.7771852 & -0.1066779 & 0.7771852 \\
\hline
\end{tabular}


Step 3. Regression coefficients for the test strategies were applied against the baseline period data:

Table 16. Regression Coefficients

\begin{tabular}{c|c|c|c}
\hline Coefficient & Demand & TM & Demand and TM \\
\hline Therms Offset (Y-Intercept) & -18.05738735 & -23.12657242 & -28.81348627 \\
Therms/GPD & 0.005677969 & 0.007915022 & 0.009010447 \\
Therms/DT & 0.326552291 & 0.332504854 & 0.335253661 \\
\hline
\end{tabular}

Table 17. Flow- and Temperature-Normalized Test Period Therms per Day

\begin{tabular}{l|c|c|c|c|c|c|c}
\hline Mode & End Date & GPD & $\begin{array}{c}\Delta \mathbf{T} \\
\left({ }^{\circ} \mathbf{F}\right)\end{array}$ & $\begin{array}{c}\text { Therms/ } \\
\text { Day }\end{array}$ & $\begin{array}{c}\text { Normalized } \\
\text { Demand } \\
\text { Usage } \\
\text { (Therms) }\end{array}$ & $\begin{array}{c}\text { Normalized } \\
\text { TM Usage } \\
\text { (Therms) }\end{array}$ & $\begin{array}{c}\text { Normalized } \\
\text { Demand and } \\
\text { TM Usage } \\
\text { (Therms) }\end{array}$ \\
\hline Baseline & $8 / 25 / 2013$ & 2288 & 57 & 15.0 & 13.4 & 13.8 & 10.8 \\
Baseline & $9 / 8 / 2013$ & 2494 & 57 & 16.5 & 14.9 & 15.7 & 12.9 \\
Baseline & $9 / 22 / 2013$ & 2544 & 59 & 17.1 & 15.7 & 16.6 & 13.9 \\
Baseline & $10 / 6 / 2013$ & 2396 & 60 & 16.4 & 15.2 & 15.9 & 13.0 \\
\hline Baseline & $10 / 20 / 2013$ & 2564 & 62 & 18.1 & 16.7 & 17.8 & 15.1 \\
Baseline & $11 / 3 / 2013$ & 2516 & 66 & 19.0 & 17.8 & 18.8 & 16.1 \\
Baseline & $11 / 17 / 2013$ & 2654 & 71 & 21.4 & 20.2 & 21.5 & 18.9 \\
Baseline & $12 / 1 / 2013$ & 2924 & 76 & 24.6 & 23.3 & 25.2 & 22.9 \\
\hline Baseline & $12 / 15 / 2013$ & 3023 & 79 & 26.6 & 25.0 & 27.1 & 25.0 \\
Baseline & $3 / 9 / 2014$ & 2970 & 104 & 36.9 & 32.6 & 34.8 & 32.7 \\
Baseline & $3 / 21 / 2014$ & 3057 & 102 & 33.8 & 32.7 & 35.1 & 33.1 \\
\hline
\end{tabular}

Step 4. The calculated percent fuel reductions for each period were averaged and used to determine annual DHW fuel reduction for each control strategy:

Table 18. Flow- and Temperature-Normalized Fuel Reductions per Baseline Period

\begin{tabular}{|c|c|c|}
\hline Demand Reduction & TM Reduction & $\begin{array}{c}\text { TM and Demand } \\
\text { Reduction }\end{array}$ \\
\hline $\mathbf{1 0} \%$ & $8 \%$ & $28 \%$ \\
\hline $\mathbf{1 0} \%$ & $5 \%$ & $22 \%$ \\
$\mathbf{8} \%$ & $3 \%$ & $19 \%$ \\
$\mathbf{7 \%}$ & $4 \%$ & $21 \%$ \\
$\mathbf{7 \%}$ & $2 \%$ & $17 \%$ \\
$\mathbf{6 \%}$ & $1 \%$ & $16 \%$ \\
$\mathbf{6 \%}$ & $0 \%$ & $12 \%$ \\
$\mathbf{5 \%}$ & $-2 \%$ & $7 \%$ \\
$\mathbf{6 \%}$ & $-2 \%$ & $6 \%$ \\
\hline $\mathbf{1 2} \%$ & $6 \%$ & $12 \%$ \\
\hline $\mathbf{3} \%$ & $-4 \%$ & $2 \%$ \\
\hline $\mathbf{7 \%}$ & $2 \%$ & $15 \%$ \\
\hline
\end{tabular}




\section{Uncertainty Propagation Calculations}

Step 1. Each test period fuel calculation was re-done with the flow uncertainty term included, and then re-done separately with the temperature uncertainty term included.

\section{Method I (Building A):}

$$
\begin{aligned}
& \text { Total DHW Fuel } \text { norm }_{\text {Flow Uncertainty }} \\
& =\text { Total DHW Fuel }_{\text {Test }} \\
& \times \frac{\text { Flow Uncertainty }{ }_{1} \times \text { Total Flow }_{\text {Base }}}{\text { Total Flow }_{\text {Test }}} \\
& \times \frac{\left(T_{\text {Supply Base }}-T_{\text {Makeup Base }}\right)}{\left(T_{\text {Supply Test }}-T_{\text {Makeup Test }}\right)}
\end{aligned}
$$

Total DHW Fuel norm $_{\text {Temperature Uncertainty }}$

$$
\begin{aligned}
& =\text { Total DHW Fuel }_{\text {Test }} \times \frac{\text { Total Flow }_{\text {Base }}}{\text { Total Flow }_{\text {Test }}} \\
& \times \frac{\left(T_{\text {Supply Base }}-T_{\text {Makeup Base }}\right)}{\left(T_{\text {Supply Test }}-T_{\text {Makeup Test }}-\text { Temp Uncertaint } \text { U }_{2^{\circ} \mathrm{F}}\right)}
\end{aligned}
$$

Where

Flow Uncertainty Un $_{1 \%}$ is a unit-less factor of 1.01

Temp Uncertainty ${ }_{2^{\circ} F}$ is two degrees Fahrenheit

The average annualized DHW fuel reduction calculation was re-performed, as given previously for building A, but with the values generated above, generating the intermediate uncertainty figures shown in Table 18.

\section{Method II (Building B):}

Gallons per Day (GPD) were re-calculated for each period with the 1.01 uncertainty factor included, and then used to replace the original GPD values in Table 13. The regression analysis was performed, as given before, using these new values. Temperature rise $(\Delta T)$ was separately re-calculated for each period, subtracting $2^{\circ} \mathrm{F}$ from each original value, and used to replace the original $\Delta \mathrm{T}$ values in Table 13. The regression analysis was again performed, giving two final sets of annualized fuel savings percentages for each control mode as shown in Table 19.

Step 2. Flowrate measurement uncertainty and temperature measurement uncertainty were then recorded individually as the deviation between the re-calculated percent fuel savings and the original percent fuel savings (shown in Tables 18 and 19). The percent uncertainties from flowrate and temperature measurement were then combined using a root-sum-square equation for each control mode.

$$
\text { Combined Uncertainty }=\sqrt{\text { Uncertainty }_{T}^{2}+\text { Uncertainty }_{F}^{2}}
$$


Where

Uncertainty $_{T}$ is the deviation of the re-calculated annual fuel savings (with the maximum temperature measurement uncertainty incorporated) from the original annual fuel savings, as a percent

Uncertainty $_{F}$ is the deviation of the re-calculated annual fuel savings (with the maximum flowrate measurement uncertainty incorporated) from the original annual fuel savings, as a percent

Table 19. Building A Uncertainty Propagation Figures

\begin{tabular}{|c|c|c|c|c|c|c|}
\hline & \multicolumn{3}{|c|}{ Percent Annual Fuel Savings } & \multicolumn{2}{|c|}{$\begin{array}{c}\text { Difference from Original } \\
\text { Value }\end{array}$} & \multirow[b]{2}{*}{$\begin{array}{c}\text { RSS } \\
\text { Uncertainty }\end{array}$} \\
\hline Mode & Original & $\begin{array}{l}\text { w/+1\% Flow } \\
\text { Uncertainty }\end{array}$ & $\begin{array}{c}\text { w/-2 }{ }^{\circ} \mathrm{F} \\
\text { Temp } \\
\text { Uncertainty }\end{array}$ & $\begin{array}{c}\text { w/+1\% } \\
\text { Flow } \\
\text { Uncertainty }\end{array}$ & $\begin{array}{c}\mathrm{w} /-2^{\circ} \mathrm{F} \\
\text { Temp } \\
\text { Uncertainty }\end{array}$ & \\
\hline Demand & $5.6 \%$ & $4.7 \%$ & $4.0 \%$ & $0.9 \%$ & $1.7 \%$ & $1.9 \%$ \\
\hline
\end{tabular}

Table 20. Building B Uncertainty Propagation Figures

\begin{tabular}{c|c|c|c|c|c|c}
\hline & \multicolumn{3}{|c|}{ Percent Annual Fuel Savings } & \multicolumn{2}{c|}{$\begin{array}{r}\text { Difference from Original } \\
\text { Value }\end{array}$} & \\
\hline Mode & Original & $\begin{array}{c}\text { w/-1\% Flow } \\
\text { Uncertainty }\end{array}$ & $\begin{array}{c}\text { w/-2 }{ }^{\circ} \mathbf{F} \\
\text { Temp } \\
\text { Uncertainty }\end{array}$ & $\begin{array}{c}\text { w/-1\% Flow } \\
\text { Uncertainty }\end{array}$ & $\begin{array}{c}\text { w/-2 }{ }^{\circ} \mathbf{F} \\
\text { Temp } \\
\text { Uncertainty }\end{array}$ & $\begin{array}{c}\text { RSS } \\
\text { Uncertainty }\end{array}$ \\
\hline Demand & $7.4 \%$ & $5.2 \%$ & $4.2 \%$ & $2.2 \%$ & $3.2 \%$ & $3.9 \%$ \\
\hline TM & $1.7 \%$ & $-0.6 \%$ & $-1.6 \%$ & $2.3 \%$ & $3.2 \%$ & $3.9 \%$ \\
\hline $\begin{array}{c}\text { TM and } \\
\text { Demand }\end{array}$ & $14.5 \%$ & $12.3 \%$ & $11.3 \%$ & $2.3 \%$ & $3.3 \%$ & $4.0 \%$ \\
\hline
\end{tabular}




\section{Appendix B. Interactivity Calculation}

\section{Space Conditioning Cost Interactivity for Domestic Hot Water Controls}

$$
\begin{aligned}
& \text { Net Cost Savings }=\text { Elec }_{\text {pump }} \times \$ / k W h+\text { Fuel }_{\text {DHW }} \\
& \qquad \times[\$ / \text { therm } \\
&
\end{aligned}
$$

Where:

Elec $c_{\text {pump }}$ is the annualized reduction in recirculation pump electricity consumption due the control strategy, in $\mathrm{kWh}$

Fuel $_{D H W}$ is the annualized reduction in DHW fuel due to the control strategy, in therms of natural gas

$\mathrm{CH}$ is the annual cooling equipment runtime, in hours

SEER is the cooling equipment efficiency, expressed here in units of therms per $100 \mathrm{kWh}$ (a 1:1 equivalence with the standard definition of Btu per watt-hour)

$H H$ is the annual heating equipment runtime, in hours

$A F U E$ is the heating equipment efficiency, as a dimensionless percentage

interaction is the proportion of recirculation loop heat transferred to conditioned space, as a percentage

8,760 is the number of hours in a year 


\section{Appendix C. Test Site Details}

Buildings $\mathrm{A}$ and $\mathrm{B}$ are neighboring three-story buildings located in Brooklyn, New York, with 54 and 48 apartments, respectively. Each has two DHW storage tanks with two dedicated two-stage gas-fired boilers and a recirculating loop with continuously operating pump. A space-heating boiler in each building serves only the corridors and lobby and both were nonfunctional during this project. Apartments are heated by individual gas-fired PTACs. 
Table 21. Building A Measurement Summary

\begin{tabular}{|c|c|c|c|c|c|c|c|c|c|c|c|}
\hline Start Date & End Date & $\begin{array}{l}\text { Control } \\
\text { System }\end{array}$ & $\begin{array}{l}\text { Supply } \\
\text { Temp } \\
\left(^{\circ} \mathrm{F}\right)\end{array}$ & $\begin{array}{c}\text { Makeup } \\
\text { Water Temp } \\
\left({ }^{\circ} \mathrm{F}\right)\end{array}$ & $\begin{array}{l}\Delta \mathrm{T} \\
\left({ }^{\circ} \mathbf{F}\right)\end{array}$ & $\begin{array}{c}\text { Return } \\
\text { Temp } \\
\left({ }^{\circ} \mathrm{F}\right)\end{array}$ & Days & GPD & $\begin{array}{c}\text { Recirc } \\
\text { Pump } \\
\text { Runtime } \\
\text { (h/day) }\end{array}$ & $\begin{array}{c}\text { DHW Fuel } \\
\text { (therms/ } \\
\text { day) }\end{array}$ & $\begin{array}{c}\text { Annual } \\
\text { Therms } \\
\text { Saved }\end{array}$ \\
\hline $8 / 25 / 2013$ & $8 / 31 / 2013$ & Demand & 134 & 63 & 71 & 94 & 7.0 & 2,617 & 0.07 & 20.3 & 419 \\
\hline $8 / 31 / 2013$ & 9/7/2013 & Baseline & 134 & 63 & 71 & 130 & 7.0 & 2,660 & 24 & 21.5 & - \\
\hline $9 / 7 / 2013$ & $9 / 14 / 2013$ & Demand & 134 & 63 & 71 & 94 & 7.0 & 2,919 & 0.09 & 20.3 & 423 \\
\hline 9/14/2013 & $9 / 21 / 2013$ & Baseline & 134 & 63 & 71 & 130 & 7.0 & 3,273 & 24 & 25.9 & - \\
\hline $9 / 21 / 2013$ & $9 / 27 / 2013$ & Demand & 133 & 63 & 71 & 81 & 5.9 & 3,364 & 0.00 & 24.5 & 523 \\
\hline 9/27/2013 & $10 / 6 / 2013$ & Baseline & 163 & 61 & 102 & 158 & 3.5 & 2,279 & 24 & 28.3 & - \\
\hline $10 / 6 / 2013$ & $10 / 12 / 2013$ & Demand & 162 & 61 & 101 & 85 & 7.0 & 2,964 & 0.00 & 25.5 & 1000 \\
\hline $10 / 12 / 2013$ & $10 / 19 / 2013$ & Baseline & 162 & 60 & 101 & 157 & 7.0 & 2,850 & 24 & 34.6 & - \\
\hline $10 / 19 / 2013$ & $10 / 26 / 2013$ & Demand & 162 & 60 & 102 & 80 & 7.0 & 3,033 & 0.00 & 32.5 & 764 \\
\hline $10 / 26 / 2013$ & $11 / 2 / 2013$ & Baseline & 161 & 57 & 104 & 157 & 7.0 & 2,768 & 24 & 35.1 & - \\
\hline $11 / 2 / 2013$ & 11/9/2013 & Demand & 161 & 55 & 106 & 79 & 7.0 & 3,010 & 0.00 & 32.6 & 936 \\
\hline $11 / 9 / 2013$ & $11 / 16 / 2013$ & Baseline & 161 & 53 & 108 & 157 & 7.0 & 2,741 & 24 & 36.6 & - \\
\hline $11 / 16 / 2013$ & $11 / 23 / 2013$ & Demand & 160 & 51 & 110 & 78 & 7.0 & 2,996 & 0.00 & 33.5 & 1155 \\
\hline $11 / 23 / 2013$ & $11 / 30 / 2013$ & Baseline & 159 & 49 & 110 & 156 & 7.0 & 3,124 & 24 & 41.9 & - \\
\hline $11 / 30 / 2013$ & $12 / 7 / 2013$ & Demand & 160 & 46 & 114 & 89 & 7.0 & 2,871 & 0.07 & 39.2 & 1002 \\
\hline $12 / 7 / 2013$ & $12 / 14 / 2013$ & Baseline & 159 & 46 & 113 & 156 & 7.0 & 2,992 & 24 & 41.9 & - \\
\hline $12 / 14 / 2013$ & $12 / 21 / 2013$ & Demand & 158 & 43 & 115 & 68 & 7.0 & 3,236 & 0.00 & 38.3 & 1313 \\
\hline $12 / 21 / 2013$ & $12 / 28 / 2013$ & Baseline & 159 & 42 & 116 & 155 & 7.0 & 3,267 & 24 & 45.9 & - \\
\hline $12 / 28 / 2013$ & $1 / 4 / 2014$ & Demand & 159 & 42 & 118 & 63 & 7.0 & 3,171 & 0.00 & 43.8 & 741 \\
\hline $1 / 4 / 2014$ & $1 / 11 / 2014$ & Baseline & 157 & 39 & 117 & 154 & 7.0 & 3,408 & 24 & 49.1 & - \\
\hline $1 / 11 / 2014$ & $1 / 18 / 2014$ & Demand & 158 & 39 & 119 & 62 & 7.0 & 3,178 & 0.00 & 45.9 & 1159 \\
\hline 1/18/2014 & $1 / 25 / 2014$ & Baseline & 156 & 40 & 116 & 154 & 6.4 & 3,370 & 24 & 48.4 & - \\
\hline $3 / 15 / 2014$ & $3 / 22 / 2014$ & Demand & 169 & 39 & 130 & 70 & 7.0 & 3,068 & 0.04 & 46.4 & 185 \\
\hline $3 / 22 / 2014$ & $3 / 29 / 2014$ & Baseline & 170 & 39 & 130 & 166 & 7.0 & 2,920 & 24 & 47.4 & - \\
\hline $3 / 29 / 2014$ & $4 / 5 / 2014$ & Demand & 169 & 40 & 129 & 65 & 7.0 & 3,290 & 0.00 & 43.4 & 1467 \\
\hline $4 / 5 / 2014$ & $4 / 12 / 2014$ & Baseline & 169 & 40 & 129 & 165 & 7.0 & 3,080 & 24 & 48.1 & - \\
\hline $4 / 12 / 2014$ & $4 / 19 / 2014$ & Demand & 171 & 39 & 133 & 70 & 7.0 & 3,122 & 0.00 & 43.7 & 1593 \\
\hline
\end{tabular}


Table 22. Building B Measurement Summary

\begin{tabular}{|c|c|c|c|c|c|c|c|c|c|c|}
\hline Start Date & End Date & $\begin{array}{l}\text { Control } \\
\text { System }\end{array}$ & $\begin{array}{c}\text { Supply } \\
\text { Temp } \\
\left({ }^{\circ} \mathrm{F}\right)\end{array}$ & $\begin{array}{c}\text { Makeup Water } \\
\text { Temp } \\
\left({ }^{\circ} \mathbf{F}\right) \\
\end{array}$ & $\begin{array}{l}\Delta \mathrm{T} \\
\left({ }^{\circ} \mathrm{F}\right)\end{array}$ & $\begin{array}{c}\text { Return } \\
\text { Temp } \\
\left({ }^{\circ} \mathrm{F}\right)\end{array}$ & Days & GPD & $\begin{array}{c}\text { Recirc Pump } \\
\text { Runtime } \\
\text { (h/day) }\end{array}$ & \begin{tabular}{|c}
$\begin{array}{c}\text { DHW Fuel } \\
\text { (therms/ } \\
\text { day) }\end{array}$ \\
\end{tabular} \\
\hline $8 / 11 / 2013$ & $8 / 18 / 2013$ & Demand & 129 & 71 & 58 & 94 & 7.0 & 2,300 & 0.19 & 13.6 \\
\hline $8 / 18 / 2013$ & $8 / 25 / 2013$ & Baseline & 130 & 73 & 57 & 128 & 7.0 & 2,288 & 24 & 15.0 \\
\hline $8 / 25 / 2013$ & $9 / 1 / 2013$ & Demand & 129 & 72 & 57 & 94 & 7.0 & 2,576 & 0.07 & 13.4 \\
\hline $9 / 1 / 2013$ & 9/8/2013 & Baseline & 129 & 72 & 57 & 127 & 7.0 & 2,494 & 24 & 16.5 \\
\hline $9 / 8 / 2013$ & $9 / 15 / 2013$ & Demand & 129 & 71 & 57 & 94 & 7.0 & 3,055 & 0.18 & 14.6 \\
\hline $9 / 15 / 2013$ & $9 / 22 / 2013$ & Baseline & 129 & 70 & 59 & 127 & 7.0 & 2,544 & 24 & 17.1 \\
\hline $9 / 22 / 2013$ & $9 / 29 / 2013$ & Demand & 129 & 70 & 59 & 95 & 7.0 & 2,711 & 0.35 & 15.6 \\
\hline 9/29/2013 & $10 / 6 / 2013$ & Baseline & 130 & 69 & 60 & 127 & 7.0 & 2,396 & 24 & 16.4 \\
\hline $10 / 6 / 2013$ & $10 / 13 / 2013$ & Demand & 129 & 69 & 60 & 95 & 7.0 & 2,750 & 0.37 & 15.0 \\
\hline $10 / 13 / 2013$ & $10 / 20 / 2013$ & Baseline & 129 & 67 & 62 & 127 & 7.0 & 2,564 & 24 & 18.1 \\
\hline $10 / 20 / 2013$ & $10 / 27 / 2013$ & Demand & 129 & 66 & 63 & 95 & 7.0 & 2,757 & 0.44 & 16.7 \\
\hline $10 / 27 / 2013$ & $11 / 3 / 2013$ & Baseline & 129 & 63 & 66 & 127 & 7.0 & 2,516 & 24 & 19.0 \\
\hline $11 / 3 / 2013$ & $11 / 10 / 2013$ & Demand & 129 & 61 & 68 & 95 & 7.0 & 2,972 & 0.52 & 17.3 \\
\hline $11 / 10 / 2013$ & $11 / 17 / 2013$ & Baseline & 129 & 58 & 71 & 126 & 7.0 & 2,654 & 24 & 21.4 \\
\hline $11 / 17 / 2013$ & $11 / 24 / 2013$ & Demand & 128 & 56 & 72 & 96 & 7.0 & 2,922 & 0.58 & 19.6 \\
\hline $11 / 24 / 2013$ & $12 / 1 / 2013$ & Baseline & 129 & 53 & 76 & 126 & 7.0 & 2,924 & 24 & 24.6 \\
\hline $12 / 1 / 2013$ & $12 / 8 / 2013$ & Demand & 128 & 52 & 77 & 96 & 7.0 & 2,985 & 0.64 & 23.2 \\
\hline $12 / 8 / 2013$ & $12 / 15 / 2013$ & Baseline & 129 & 50 & 79 & 126 & 7.0 & 3,023 & 24 & 26.6 \\
\hline $12 / 15 / 2013$ & $12 / 22 / 2013$ & Demand & 128 & 47 & 81 & 96 & 7.0 & 3,171 & 0.68 & 24.9 \\
\hline $12 / 22 / 2013$ & $12 / 29 / 2013$ & TM & 129 & 47 & 82 & 126 & 7.0 & 2,933 & 24 & 27.1 \\
\hline $12 / 29 / 2013$ & $1 / 5 / 2014$ & TM & 129 & 45 & 84 & 97 & 7.0 & 3,535 & 0.82 & 25.2 \\
\hline $1 / 5 / 2014$ & $1 / 12 / 2014$ & $\mathrm{TM}$ & 127 & 42 & 84 & 124 & 7.0 & 3,375 & 24 & 26.6 \\
\hline $1 / 12 / 2014$ & $1 / 19 / 2014$ & $\begin{array}{c}\text { Demand + } \\
\text { TM }\end{array}$ & 130 & 42 & 88 & 97 & 7.0 & 3,282 & 0.70 & 25.0 \\
\hline 1/19/2014 & 1/26/2014 & $\mathrm{TM}$ & 127 & 41 & 86 & 124 & 7.0 & 3,073 & 24 & 27.3 \\
\hline $1 / 26 / 2014$ & $2 / 2 / 2014$ & $\begin{array}{c}\text { Demand }+ \\
\text { TM }\end{array}$ & 128 & 39 & 89 & 97 & 7.0 & 3,624 & 0.92 & 24.9 \\
\hline $2 / 2 / 2014$ & 2/9/2014 & $\mathrm{TM}$ & 127 & 40 & 87 & 124 & 7.0 & 3,242 & 24 & 26.6 \\
\hline
\end{tabular}


\begin{tabular}{l|l} 
u.s. DEPARTMENT OF & Energy Efficiency \& \\
Renewable Energy
\end{tabular}

\begin{tabular}{|c|c|c|c|c|c|c|c|c|c|c|}
\hline Start Date & End Date & $\begin{array}{l}\text { Control } \\
\text { System }\end{array}$ & $\begin{array}{c}\text { Supply } \\
\text { Temp } \\
\left({ }^{\circ} \mathbf{F}\right)\end{array}$ & $\begin{array}{c}\text { Makeup Water } \\
\text { Temp } \\
\left({ }^{\circ} \mathbf{F}\right)\end{array}$ & $\begin{array}{l}\Delta \mathrm{T} \\
\left({ }^{\circ} \mathbf{F}\right)\end{array}$ & $\begin{array}{c}\text { Return } \\
\text { Temp } \\
\left({ }^{\circ} \mathbf{F}\right)\end{array}$ & Days & GPD & $\begin{array}{c}\text { Recirc Pump } \\
\text { Runtime } \\
\text { (h/day) }\end{array}$ & \begin{tabular}{|c}
$\begin{array}{c}\text { DHW Fuel } \\
\text { (therms/ } \\
\text { day) }\end{array}$ \\
\end{tabular} \\
\hline $2 / 9 / 2014$ & $2 / 16 / 2014$ & $\begin{array}{c}\text { Demand + } \\
\text { TM }\end{array}$ & 131 & 40 & 91 & 97 & 7.0 & 3,498 & 0.70 & 25.1 \\
\hline $2 / 16 / 2014$ & $2 / 21 / 2014$ & TM & 131 & 40 & 91 & 127 & 5.0 & 3,129 & 24 & 26.8 \\
\hline $2 / 21 / 2014$ & $3 / 2 / 2014$ & Demand & 144 & 41 & 104 & 97 & 7.0 & 3,352 & 0.42 & 30.7 \\
\hline $3 / 2 / 2014$ & $3 / 9 / 2014$ & Baseline & 144 & 40 & 104 & 140 & 7.0 & 2,970 & 24 & 36.9 \\
\hline $3 / 9 / 2014$ & $3 / 16 / 2014$ & Demand & 145 & 42 & 102 & 97 & 7.0 & 3,327 & 0.00 & 31.0 \\
\hline $3 / 16 / 2014$ & $3 / 21 / 2014$ & Baseline & 145 & 42 & 102 & 141 & 5.2 & 3,057 & 24 & 33.8 \\
\hline
\end{tabular}




\section{Monitoring Equipment}

In July 2013 monitoring equipment was installed, one-time flow measurements were recorded and data acquisition began. The following equipment was installed in each building:

- 1 - OPTO 22 Datalogger and enclosure with SNAP PAC R-1 Programmable Automation Controller

- 7 - Veris 300 Current Switches

- 12 - Watlow Thermocouples

- 1 (site A) or 2 (site B) - Omega water flow meter(s) (Two model FTB-4807 flow sensors were installed at building $\mathrm{B}$ in parallel because a properly-sized single sensor was unavailable.)

- 9 - temperature sensors connected to HOBO data loggers on the primary DHW recirculation loop.

Sensor and equipment locations are presented in Figure 5.

\section{Data Point List}

Continuously monitored data points with their descriptions are provided in Table 20. The data points were used to calculate total energy consumption by the DHW system for each control strategy. In addition, HOBO data loggers were mounted at three different locations on the primary DHW recirculation loop in the first floor ceiling of each building to measure return water, supply water and pipe chase air temperatures and to facilitate potential future modeling.

Table 23. Data Points Collected Continuously at Sites A and B

\begin{tabular}{|c|c|c|c|}
\hline Data Points & Description & Sensor & Unit \\
\hline FMW & Makeup water flow rate & $\begin{array}{c}\text { Omega FTB-4810 } \\
\text { or FTB-4807 }\end{array}$ & $\mathrm{Gal} / \mathrm{min}$ \\
\hline $\mathbf{T}_{\mathbf{C}}$ & Cold (city) water Inlet Temp & Type-T TC & ${ }^{\circ} \mathrm{F}$ \\
\hline Ts & Hot water temp to building & Type-T TC & ${ }^{\circ} \mathrm{F}$ \\
\hline $\mathbf{T}_{\mathbf{S 1}}$ & Hot water temp exiting tank 1 & Type-T TC & ${ }^{\circ} \mathrm{F}$ \\
\hline $\mathbf{T}_{\mathbf{S 2}}$ & Hot water temp exiting tank 2 & Type-T TC & ${ }^{\circ} \mathrm{F}$ \\
\hline $\mathbf{T}_{\mathbf{T} 1}$ & Water temperature tank 1 thermowell & Type-T TC & ${ }^{\circ} \mathrm{F}$ \\
\hline $\mathbf{T}_{\mathbf{T} 2}$ & Water temperature tank 2 thermowell & Type-T TC & ${ }^{\circ} \mathrm{F}$ \\
\hline $\mathbf{T}_{\mathbf{R}}$ & Recirculation water temp from building & Type-T TC & ${ }^{\circ} \mathrm{F}$ \\
\hline Тво1 & Supply water temperature of boiler(1) & Type-T TC & ${ }^{\circ} \mathrm{F}$ \\
\hline $\mathbf{T}_{\text {BI1 }}$ & Return water temperature to boiler (1) & Type-T TC & ${ }^{\circ} \mathrm{F}$ \\
\hline Тво2 & Supply water temperature of boiler (2) & Type-T TC & ${ }^{\circ} \mathrm{F}$ \\
\hline $\mathbf{T}_{\text {BI2 }}$ & Return water temperature to boiler (2) & Type-T TC & ${ }^{\circ} \mathrm{F}$ \\
\hline $\mathbf{T}_{\mathrm{AI1}}$ & Room air temperature in boiler room & Type-T TC & ${ }^{\circ} \mathrm{F}$ \\
\hline$* \mathbf{T S}_{\mathrm{S}-\mathrm{CH} 1}$ & Supply water temperature upper floor & Hobo UX-100 & ${ }^{\circ} \mathrm{F}$ \\
\hline$* \mathbf{T}_{\mathrm{A}-\mathrm{CH} 1}$ & Space air temperature pipe chase & Hobo U12 & ${ }^{\circ} \mathrm{F}$ \\
\hline$* \mathbf{T}_{\mathrm{R}-\mathrm{CH} 1}$ & Return water temperature & Hobo U12 & ${ }^{\circ} \mathrm{F}$ \\
\hline SPR & Runtime/status of recirculation pump & Veris CT & minutes \\
\hline SP1 & Runtime/status of boiler (1) pump & Veris CT & minutes \\
\hline SP2 & Runtime/status of boiler (2) pump & Veris CT & minutes \\
\hline Sв & Space heating boiler status & Veris CT & minutes \\
\hline
\end{tabular}

*These sensors were mounted at three different locations at each building to collect data for potential future modeling of the DHW system. 


\section{Status of Boilers and Recirculation Pump}

At these sites, there are two 2-stage domestic hot water boilers that operate periodically and one space heating boiler to provide heating for building common areas. PTAC systems provide heating and cooling for apartments. One of the DHW boilers and the space heating boiler were not functioning at either site. Current switches (Model: Veries 300) were installed to monitor the status of the recirculation pump (SPR), both stages of DHW boiler 1 and DHW boiler 2, pumps connected between the DHW boiler and the tanks, and the space heating boiler. Veris 300 current switches were installed on or near the unit. The SPR CT was installed on the aquastat controlling the recirculation pump. The DHW switches were installed on the natural gas solenoid valves on the boiler. The space heating boiler switch was installed on the power to the boiler unit.

Figure 11 to Figure 13 show the locations of the current switches.

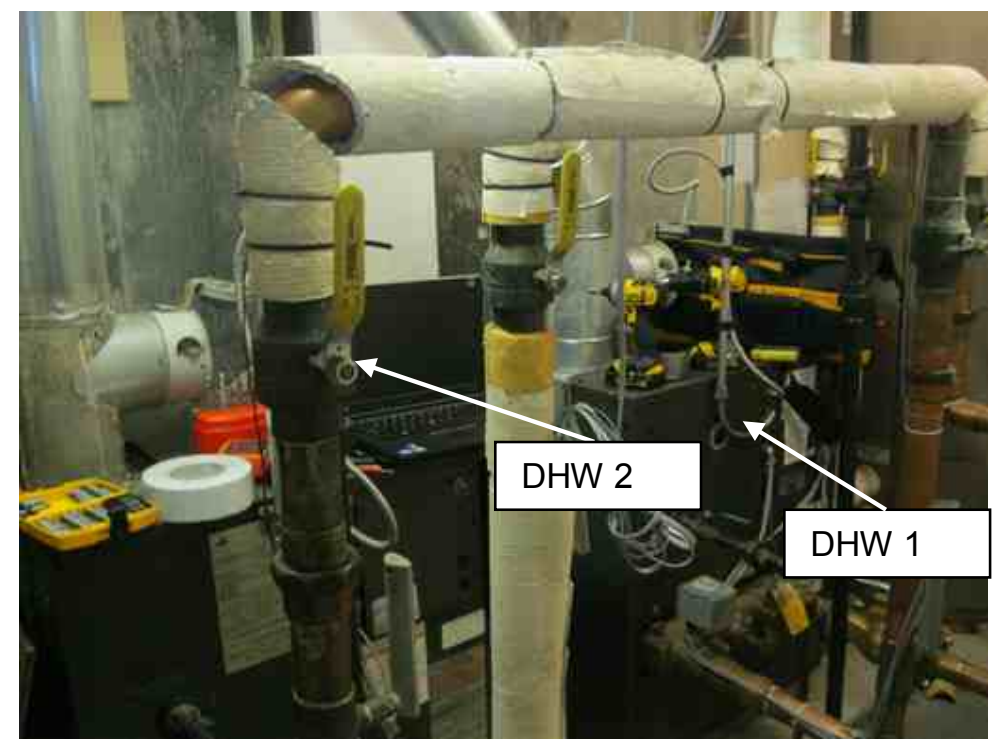

Figure 11. DWH boilers 


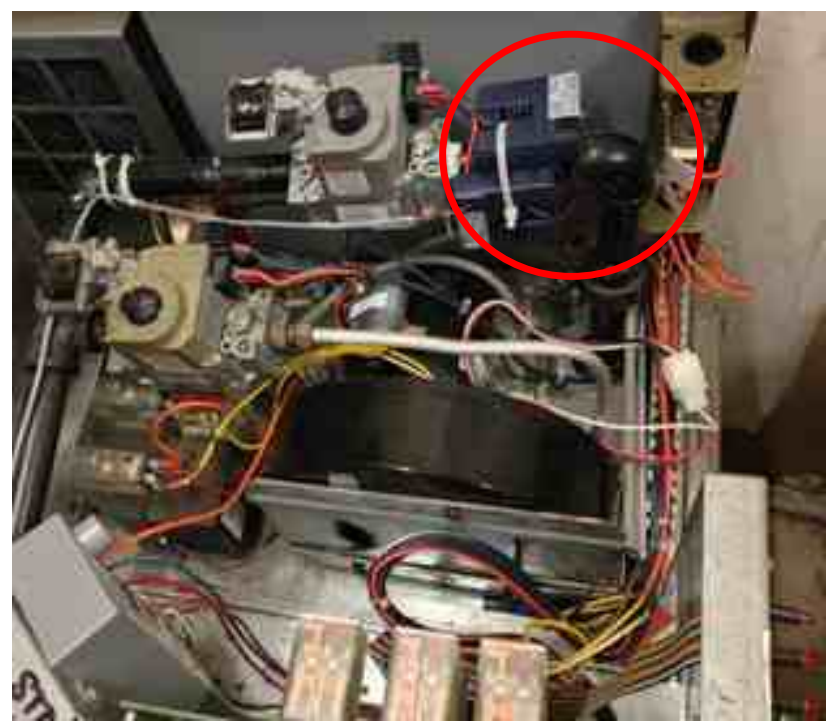

Figure 12. Current switch to monitor DHW boiler runtime (SB)

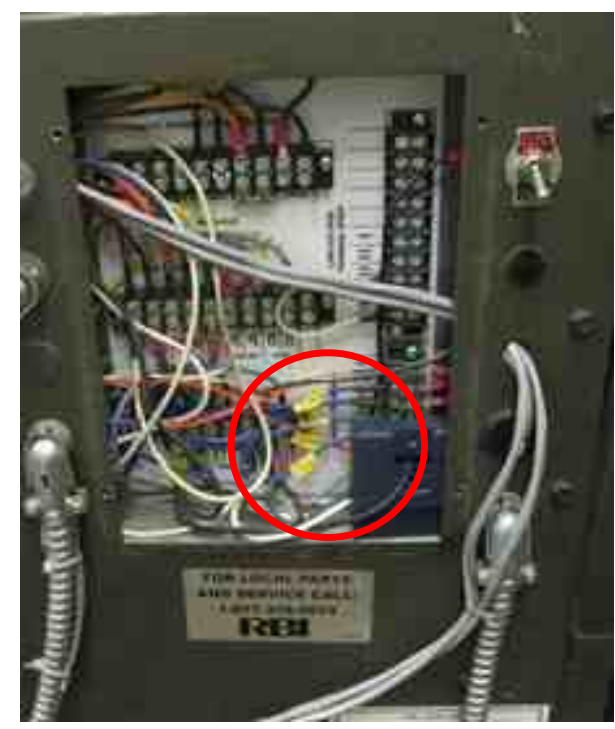

Figure 13. Current switch to monitor runtime of the pump between the DHW boiler and the tanks

\section{Temperature Sensors}

Temperature data were acquired for hot water supply to the building $\left(\mathrm{T}_{\mathrm{S}}\right)$, recirculation water $\left(T_{R}\right)$, cold or makeup water $\left(T_{C}\right)$, DHW boilers input $\left(T_{\mathrm{BI}}, T_{\mathrm{BI}}\right)$, DHW boilers output $\left(\mathrm{T}_{\mathrm{BO}}\right.$, $\mathrm{T}_{\mathrm{BO} 2}$ ), and ambient room temperature $\left(\mathrm{T}_{\mathrm{AI}}\right)$. Figure 14 to Figure 16 show locations of thermocouples to measure these temperatures.
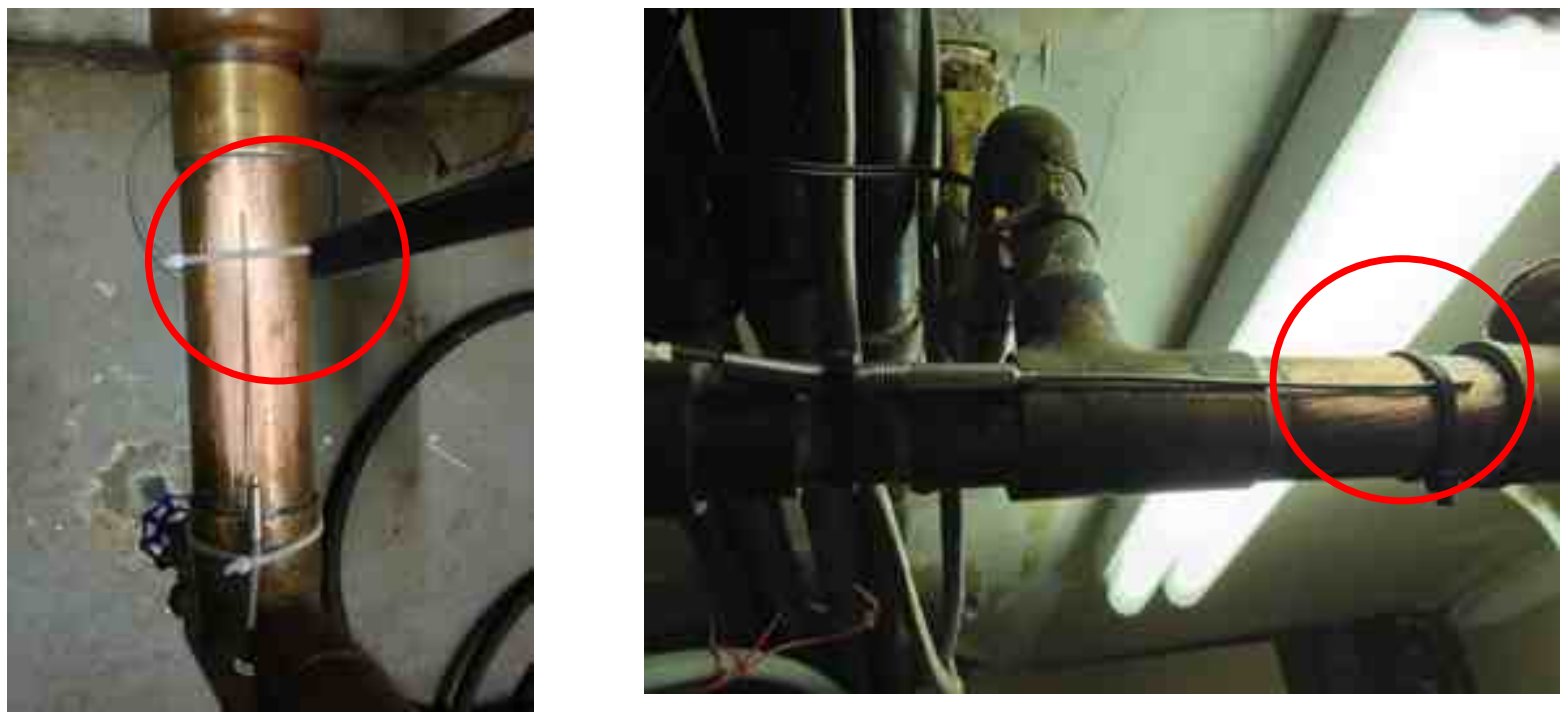

Figure 14. Supply water temperature (TS, left), recirculation loop temperature (TR, right) 


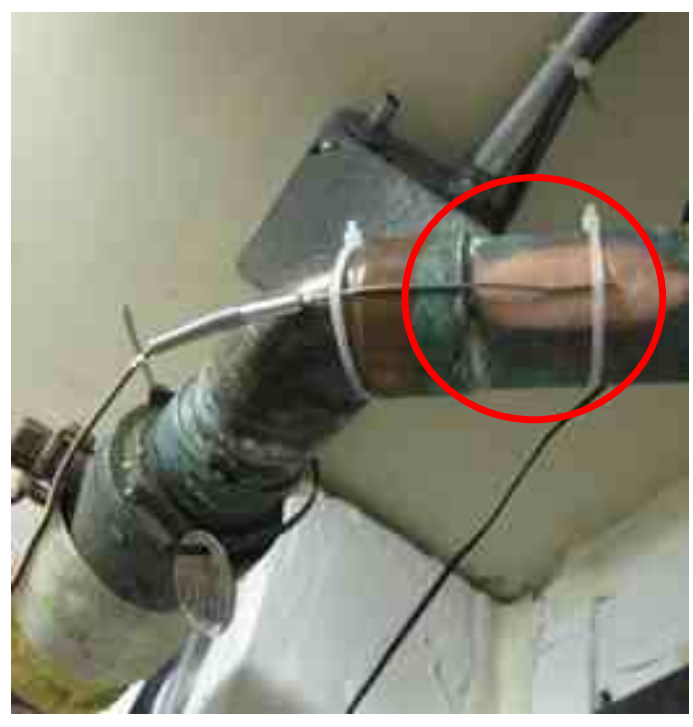

Figure 15. Cold/makeup water T (TC)

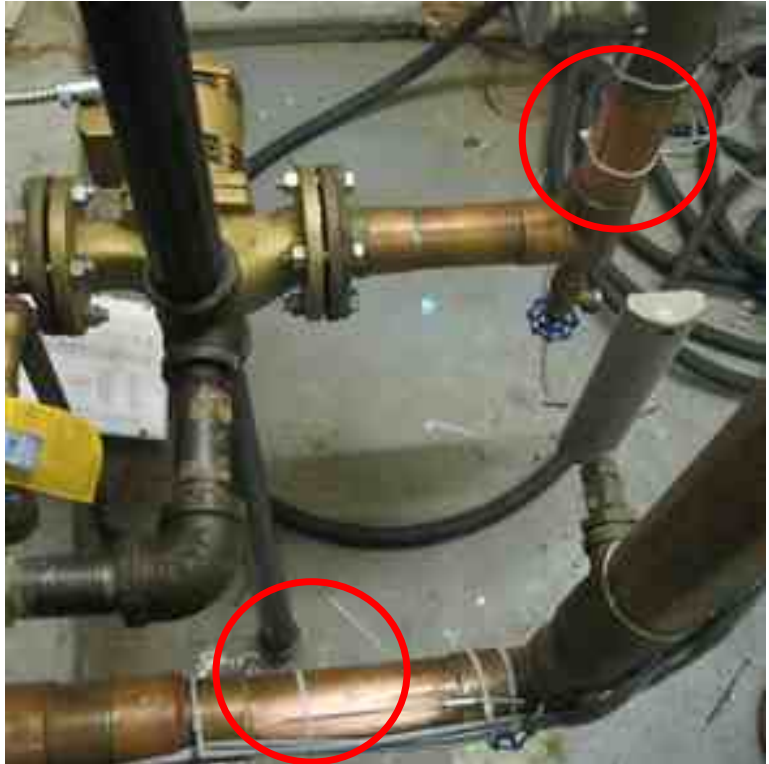

Figure 16. Boiler input and output T sensors

\section{Flow Sensor}

An Omega FTB-4810 (1" flow sensor) was installed at building A that can measure from 0.5-25 GPM at an accuracy of $+/-1 \%$; two Omega FTB-4807 sensors that have a measurement range of 0.2-15 GPM were installed in parallel at building B. Both models provide 220 pulses per gallon. These flow sensors were installed to monitor total domestic hot water consumption in the buildings. The flow sensors were installed on the cold (makeup) water line to the hot water tank. Figure 17 shows the installed flow sensor.
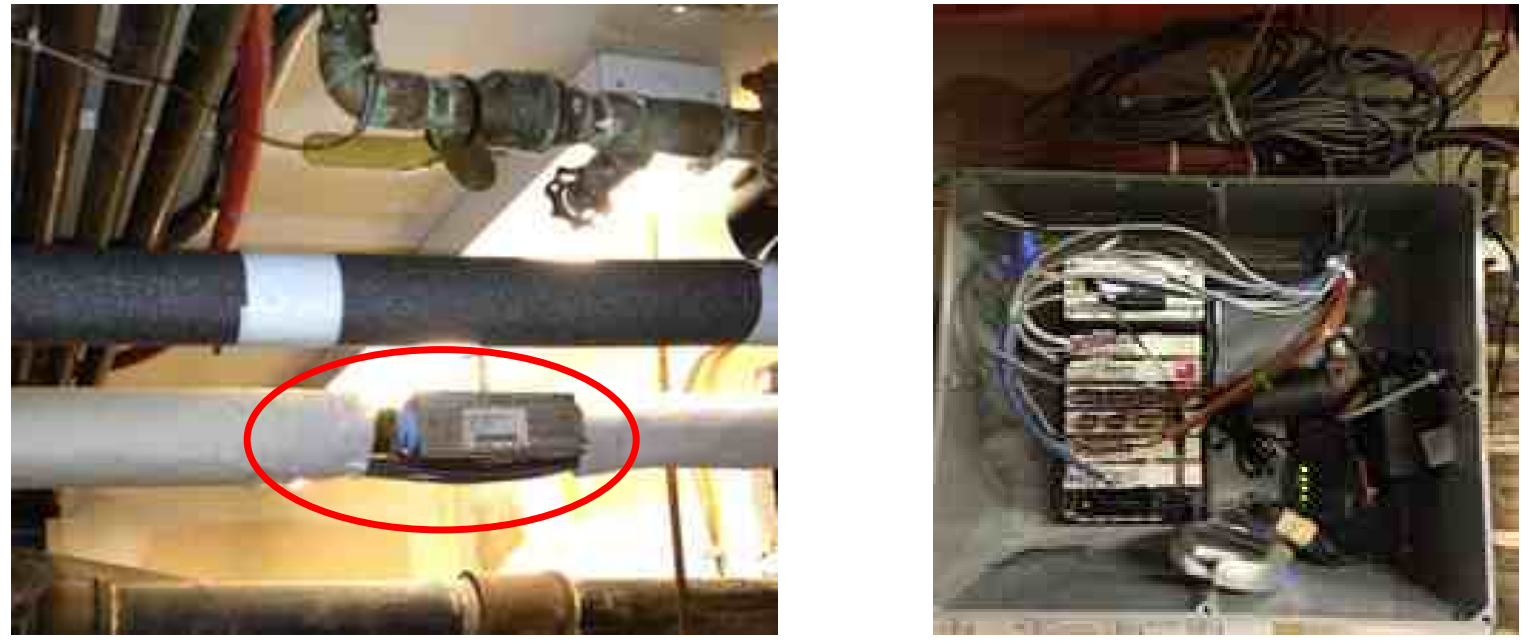

Figure 17. Flow sensor (left), and OPTO 22 data logger (right) 
As shown above, twelve thermocouples were used to measure temperatures at various locations. In order to keep one reference temperature for all temperature sensors, one OPTO 22 data logger was used.

\section{Gas Consumption}

These buildings each have a single gas meter to measure the natural gas consumption of the dedicated DHW boilers and one space heating boiler. Manually recorded gas meter readings were used to calculate the efficiency of the DHW boilers.

\section{One-Time Flow Measurements}

A Portaflow ultrasonic flow meter was used to take one-time flow measurements for the recirculation loop and the loop between the DHW boilers and the tanks. The following tables show the results.

Table 24. One-Time Flow Measurements at Building A Using Ultrasonic Flow Meter

\begin{tabular}{c|c|c|c}
\hline Location & $\begin{array}{c}\text { Nominal } \\
\text { Pipe Size }\end{array}$ & $\begin{array}{c}\text { Flow } \\
\text { (GPM) }\end{array}$ & $\begin{array}{c}\text { Average Flow } \\
\text { (GPM) }\end{array}$ \\
\hline FR & $1.25^{\prime}$ & $11.0,10.8,11.2$ & 11.0 \\
FB1 & $2.5^{\prime}$ & 0 & 0 \\
FB2 & $2.5^{\prime}$ & $44.3,44.1,44.6$ & 44.3 \\
\hline
\end{tabular}

Table 25. One-Time Flow Measurements at Building B Using Ultrasonic Flow Meter

\begin{tabular}{c|c|c|c}
\hline Location & $\begin{array}{c}\text { Nominal } \\
\text { Pipe Size }\end{array}$ & $\begin{array}{c}\text { Flow Measurements } \\
\text { (GPM) }\end{array}$ & $\begin{array}{c}\text { Average Flow } \\
\text { (GPM) }\end{array}$ \\
\hline FR & $1.25^{\prime}$ & $6.7,6.5,7.0$ & 6.73 \\
FB1 & $2.55^{\prime}$ & $46.0,45.9,46.1$ & 46.0 \\
FB2 & $2.5{ }^{\prime}$ & $44.2,44.0,44.5$ & 44.23 \\
\hline
\end{tabular}

\section{Control Hardware}

Demand controls were installed at sites A and B. TM control was installed at site B only. 


\section{Appendix D. Common Domestic Hot Water Mixing Valves}

Table 26. DHW Tempering Valves

\begin{tabular}{|c|c|c|c|c|}
\hline Manufacturer & Model & Location & $\begin{array}{l}\text { Approved for } \\
\text { Intermittent } \\
\text { Recirculation }\end{array}$ & Notes \\
\hline Apollo Valve & $\begin{array}{l}\text { MVA, } \\
\text { MVB, } \\
\text { MVC, } \\
\text { MVHL } \\
\text { series }\end{array}$ & Matthews, NC & Yes & $\begin{array}{l}\text { Controls water temperature during all } \\
\text { flow conditions }\end{array}$ \\
\hline Leonard & & Cranston, RI & Yes & $\begin{array}{l}\text { High-low line up of products work } \\
\text { with any pump controls with a } \\
\text { thermostatic mixing valve and will } \\
\text { not void warranty }\end{array}$ \\
\hline $\begin{array}{c}\text { Lawler } \\
\text { Manufacturin } \\
\mathbf{g}\end{array}$ & 800 series & $\begin{array}{l}\text { Indianapolis, } \\
\text { IN }\end{array}$ & Yes & $\begin{array}{l}\text { Does not void 1-year warranty; valve } \\
\text { is a "single valve" high-low } \\
\text { thermostatic mixing valve with } \\
\text { failure protection }\end{array}$ \\
\hline Powers/Watts & 1170 & $\begin{array}{l}\text { North Andover, } \\
\text { MA }\end{array}$ & Yes & $\begin{array}{l}\text { Recommends creating a heat trap on } \\
\text { the hot side to prevent convection } \\
\text { from affecting heating element }\end{array}$ \\
\hline $\begin{array}{c}\text { Towle } \\
\text { Whitney }\end{array}$ & & Hookset, NH & Yes & $\begin{array}{l}\text { Recommends using an aquastat } \\
\text { control for the recirculation pump }\end{array}$ \\
\hline Armstrong & $420 \mathrm{R}$ & $\begin{array}{l}\text { Three Rivers, } \\
\text { MI }\end{array}$ & Yes & $\begin{array}{l}\text { Thermostatic mixing valve 420R } \\
\text { does not require constant circulation; } \\
\text { digital valves such as the "Brain" do } \\
\text { require constant flow }\end{array}$ \\
\hline Bradley & & $\begin{array}{l}\text { Menominee } \\
\text { Falls, WI }\end{array}$ & Yes & $\begin{array}{l}\text { Recommends using an aquastat } \\
\text { control for the recirculation pump }\end{array}$ \\
\hline $\begin{array}{l}\text { Caleffi North } \\
\text { America }\end{array}$ & $\begin{array}{l}5230 \\
\text { High-flow } \\
\text { adjustable } \\
\text { TMV }\end{array}$ & Milwaukee, WI & No & $\begin{array}{l}\text { Has no product that would allow for } \\
\text { pump control }\end{array}$ \\
\hline Holby & & Newark, NJ & No & $\begin{array}{l}\text { Has no product that would allow for } \\
\text { pump control }\end{array}$ \\
\hline Symmons & & Braintree, MA & No & $\begin{array}{l}\text { Has no product that would allow for } \\
\text { pump control }\end{array}$ \\
\hline Heat Timer & & Fairfield, NJ & No & $\begin{array}{l}\text { Electronic mixing valve warranties } \\
\text { will not be voided by pump control } \\
\text { use, but potential for unsafe } \\
\text { temperatures possible according to } \\
\text { manufacturer }\end{array}$ \\
\hline
\end{tabular}




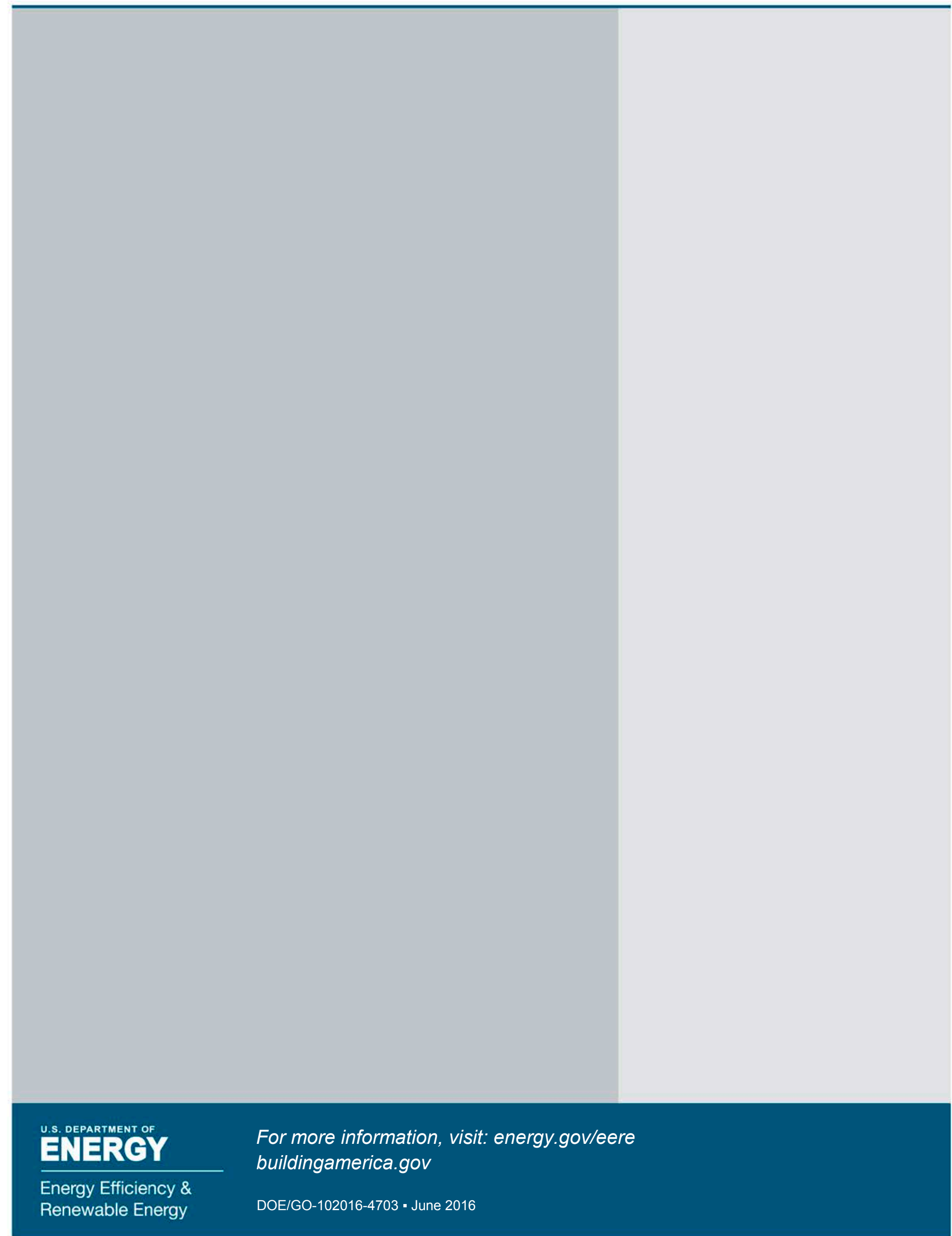

